Tugay, B., Duran, H. (2021). "Etnik Çatışmalar ve Barış Çalışmaları Üzerine Politik Psikolojik Bir İnceleme”, Eskişehir Osmangazi Üniversitesi iiBF Dergisi, 16(2), 463 - 488.

Doi: 10.17153/oguiibf.890202

Başvuru: 3.3.2021 Kabul: 30.4.2021

Araştırma Makalesi/Research Article

\title{
Etnik Çatışmalar ve Barış Çalışmaları Üzerine Politik Psikolojik Bir inceleme ${ }^{1}$
}

\begin{tabular}{|c|c|}
\hline $\begin{array}{l}\text { Etnik Çatışmalar ve Barış Çalışmaları Üzerine Politik } \\
\text { Psikolojik Bir İnceleme }\end{array}$ & $\begin{array}{l}\text { A Political Psychological Analysis on Ethnic Conflicts } \\
\text { and Peace Studies }\end{array}$ \\
\hline 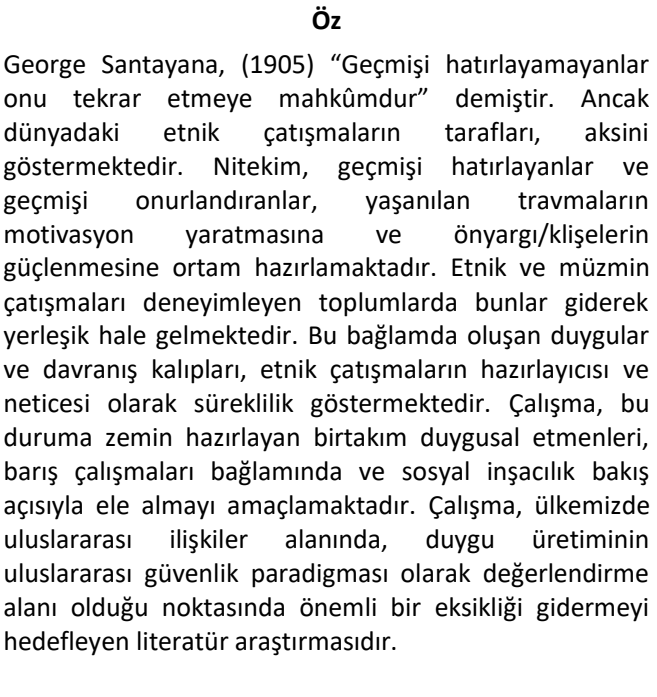 & $\begin{array}{l}\text { Abstract } \\
\text { George Santayana said, "Those who cannot remember } \\
\text { the past are contemned to repeat it." However, parties } \\
\text { of ethnic conflicts around the world show otherwise. So, } \\
\text { those who remember the past and those who honor the } \\
\text { past prepare the environment for the experienced } \\
\text { traumas to create motivation and to strengthen the } \\
\text { prejudices and stereotypes. These are increasingly } \\
\text { established in societies that experience ethnic and } \\
\text { intractable conflicts. In this context, formed emotions } \\
\text { and behavioral patterns show continuity as a } \\
\text { preparatory and also a consequence of ethnic conflicts. } \\
\text { This study aims to deal with some emotional factors that } \\
\text { predispose to this situation in the context of peace } \\
\text { studies from a social constructivist perspective. The } \\
\text { study is literature research aiming to eliminate an } \\
\text { important deficiency in the field of international } \\
\text { relations in our country in the point that emotion } \\
\text { production is an area of evaluation as an international } \\
\text { security paradigm. }\end{array}$ \\
\hline $\begin{array}{l}\text { Anahtar Kelimeler: Etnosantrizm, Çatışma, Barış, } \\
\text { Travma, Bellek }\end{array}$ & $\begin{array}{l}\text { Keywords: Ethnocentrism, Conflict, Peace, Trauma, } \\
\text { Memory }\end{array}$ \\
\hline \multicolumn{2}{|l|}{$\begin{array}{c}\text { Araştırma ve } \\
\text { Yayın Etiği } \\
\text { Beyanı }\end{array}$} \\
\hline \multicolumn{2}{|c|}{$\begin{array}{l}\text { Çalışmanın tamamı iki yazarla birlikte oluşturulmuştur. Bununla birlikte birinci yazarın katkısı \%65, ikinci yazarın } \\
\text { katkısı \%35 düzeyindedir. }\end{array}$} \\
\hline Yazarlar açısından ya da üçüncü taraflar açısında & çalışmadan kaynaklı çıkar çatışması bulunmamaktadır. \\
\hline
\end{tabular}

\footnotetext{
${ }^{1}$ Bu çalışma İstanbul Üniversitesi Sosyal Bilimler Enstitüsü Siyaset Bilimi ve Uluslararası İlişkiler Anabilim Dalı'nda yürütülen doktora tez çalışmasından türetilmiştir.

2 İstanbul Üniversitesi SBF Siyaset Bilimi ve Uluslararası İlişkiler Bölümü, burcu.tugay@ogr.iu.edu.tr

${ }^{3}$ Doç. Dr., İstanbul Üniversitesi SBF Siyaset Bilimi ve Uluslararası İlişkiler Bölümü, hasan.duran@istanbul.edu.tr
} 


\section{Giriş}

Son on yıllarda Uluslararası iliş̧kiler disiplini ciddi bir değişim geçirmiştir. Özellikle eleştirel teorilerin klasik tartışmalara eklemlenmesiyle birlikte uluslararası sistemde daha önce öne çıkmayan kültür, zihin, anlam ve travma gibi kavramlar literatürde önemli çalışma alanları olmuştur. Postpozitivist teorilerle birlikte uluslararası sistem daha soyut kavramlarla ilişkilendirilmiştir. Örneğin "Sosyal İnşacılık (Constructivism)"ın önemli temsilcisi olan ve kültür, zihin, düşünce gibi kavramları inceleyerek uluslararası yapıya sosyolojik bir boyut kazandıran Alexander Wendt'e göre uluslararası siyaset çıkarlardan oluşmakta ve çıkarlar da düşüncelerden oluşmaktadır. Sosyal ve Politik Psikoloji de uluslararası sistemin doğası hakkında önemli tezler sunmaktadır. Örneğin, Herbert C. Kelman (1997), sosyal psikolojik süreçleri çatışmayı tırmandıran dinamikler olarak nitelendirdiğinden uluslararası çatışmanın doğasına ilişkin sosyal psikolojik yaklaşımların gerekliliğini vurgulamaktadır. Nitekim çatışma, insanların yalnızca rasyonel çıkar hesaplamaları ile değil kolektif korku ve ihtiyaçları tarafından da yönlendirilmektedir (Kelman, 1997).

Çatışma Çözümü ve Barış Çalışmaları alanlarında çalışan pek çok akademisyen ve araştırmacı, müzmin çatışma senaryolarının evriminde tarihin ve belleğin önemini kabul etmiştir. Müzmin çatışmaların birçoğunun nesiller boyu sürme nedeni, hem bireyler hem de gruplar için tarihin ve belleğin imajlarının kuşaklar arası aktarımıdır. Bu noktada toplumların tarihlerini nasıl içselleştirdikleri ve kolektif hafızayı nasıl işledikleri, uzun vadeli çatışmaları motive eden dinamiklerin ayrılmaz bir özelliği haline gelmektedir. Günümüzde iç ve etnik çatışmaların sürekliliği, Uluslararası iliş̧kiler disiplininin son on yıllarda çatışma çözümleri ve barış araştırmalarında ciddi çaba gösterdiği alanlardır. Yakın tarihli çalışmalar, etnik çatışmaların büyük ölçüde iç meseleler olduğu varsayımının artık sürdürülebilir olmadığını da göstermiştir. Etnik çatışma olgusu, genellikle mevcut bir devletin sınırları içindeki bir anlaşmazlığı içerdiği ölçüde "iç" mesele olarak ele alınabilir (Singh, 2002: 74-78).

Etnik çatışmalarda sebep olarak gösterilen kimlik algısı, önyargılar, anılar ve anlatılar toplumda duygu üretiminin tetikleyicisidirler. Duygular, çeşitli uyaranlara bağlı olarak ortaya çıksalar da tutumsal bir bileşen olduklarından, çoğu zaman bilişseldirler. Geçmişte yaşanılan duygular, şimdinin ve geleceğin tutumlarında belirleyici olabilir. "Duygular, gruplar arası tutumların kutuplaşmasına yol açan grup düzeyinde psikolojik süreçleri harekete geçirir" (McDoom, 2012: 119). Özellikle sosyal gruplara yönelik tutumlar, genellikle değişime karşı oldukça dirençlidir. Önyargı, klişe ve ayrımcılık, etnosantrik belirleyiciler olarak sosyal ve kültürel yaşamda kök salmakta ve kişinin iç gruba yönelik ve dış gruplara karşı tutumları arasında bağlantı kurmaktadır. Bu çalışmada "dış grubun algılanan insanlığı (Schwartz ve Struch, 1989: 151)" klişeler ve önyargılar çerçevesinde ele alınırken, tutumların gruplararası dinamiklere yönelik etkisi gözden geçirilmiştir. Vurgulanmak istenen, grup normlarının doğasının, insanların saldırgan veya dışlayıcı davranış biçimlerini şekillendirmesi ile ilişkilendirebileceği üzerinedir. Bu çalışmada, müzmin çatışmaların temel motivasyonu olarak etnosantrik eğilimlerin önemi ön plana çıkarılmıştır. Etnosantrizmin ne olduğuna ve belirleyicilerine yönelik kısa bir açıklamanın ardından etnosantrik davranışların biliş, duygu ve davranışsal eğilim olma özelliklerini detaylandıran bir başlıkla devam edilmiştir.

Çalışmada etnosantrizmin yakınsama derecesinin duygu üretiminde önemli bir katalizör görevi gördüğü ve güçlü sosyal sınırlar oluşturduğuna değinildikten sonra etnosantrik yönelimi arttıran üç temel başlıktan bahsedilecektir: "Kollektif Bellekte Seçilmiş Travmalar ve Anlatılar" başlığında seçilmiş travma ve anlatı çerçevelerinin nasıl sosyal sınır haline getirildiği ve 
düşmanı bir kimlik tanımlayıcısı olarak ele alındığından bahsedilirken, ikinci alt başlık olan "Sınırlar ve Bölgesel Sorunlar" da ise tarihsel hesaplaşmalar/çekişmeler ve mağduriyet hissinin bir arada yaşamayı zorlaştırdığına dikkat çekilecektir. Son alt başlık olan "Lider-izzleyici Etkileşiminin Önemi”nde ise iktidar kaynağı olarak liderin, izleyiciler üzerindeki yönlendirici etkisine değinilecektir. Geçtiğimiz on yıllarda uluslararası ilişkilere egemen olan sistem düzeyinde kuramlaştırma, lider düzeyindeki düşünceleri arka plana itmiştir. Çalışmada lider faktörüne değinmede amaç, bu eksikliği gidermek ve liderlerin genellikle toplum üyelerini (izleyenleri) tek bir amaca (olumlu veya olumsuz anlamda) kanalize edebilecek ve çatışmaların devamına karar verebilecek yetiye sahip kimseler olmasına vurgu yapmaktır. Bu nedenle liderlerin siyasi karar alımında deneyim ve karakter özelliklerinin etkisini hesaba katmak, siyasi davranış modellerini anlamaya yönelik önemlidir (Horowitz ve Starn, 2014). Bu alt başlıklar sosyal olarak inşa edilen kimlik imajlarının, sekter nefretler gibi duygu üretimlerini teşvik ettiği ve müzmin çatışmaları beslediği hipotezine katkı sunmayı amaçlamaktadır. Son ana başlık olarak "Etnik Çatışmalarda Barış İnşa Süreci"nde belirtilmek istenen müzmin çatışmaların çözümüne yönelik uluslararası girişimlerde, üstü örtük veya aleni etnosantrik nefret söylemlerinin azaltılması girişimlerinin, etnik gruplar arasında "güven tesisi"nin inşası adına önemli olduğuna vurgu yapmaktır. Böylece bu çalışma, ülkemizde Uluslararası iliş̧kiler alanında çok çalışılmayan küresel siyasetteki duygu üretimi, eğilim ve travma gibi unsurlara dikkat çekmektedir.

Özetle çalışmanın değerlendirdiği ve işaret ettiği unsurlar üç yönlüdür: (1) Kollektif hafızada anlatılarla canlı tutulan duygular, toplumların etnosantrik eğilimlerini arttırmakta ve müzmin çatışmaların yakıtı haline gelmektedir. (2) Etnik çatışmalar, sadece çatışan tarafların bir meselesi olmaktan öte, duygu üretimi sayesinde uluslararası toplumu, güvenliği ve sistemi de etkilemektedir. (3) Son olarak etnosantrik duyguların zedelediği güven ortamında uluslararası pragmatik tutumların ekonomik iyileştirici olmaktan ziyade taraflar arasında kültürel ve karşılıklı iş birliğini artırıcı yönde olmasının barışı daha mümkün kılacağıdır. Dolayısıyla temel varsayım, uluslararası aktör ve kuruluşlar, toplumların içerisinde hüküm süren sekter nefret ve tutumların iyileştirilmesine zemin hazırlamadığı sürece, bu toplumlardaki çatışma dinamiğinin ateşini söndüremeyeceği savına dayanmaktadır.

\section{2. "Etnosantrizm"in Tanımı ve Belirleyicileri}

Kişinin kendi grubunun halktarzlarının (folkways) başkalarının yaptıklarından daha üstün ve kendi grubunun her şeyin merkezinde olduğunu varsayan ve literatürde etnik merkeziyetçilik olarak da bilinen "Etnosantrizm" kavramı, yirminci yüzyılın başlarında William Graham Sumner tarafından ortaya atılmıştır (Kinder ve Kam, 2010: 1; Sumner, 1906). Kavramı literatüre kazandıran Sumner, Hobbesçu kaynakların kıt olduğu bir dünyada, çatışmadan ortaya çıkan grup içi dayanışma ve grup dışı düşmanlık kavramlarının ikisini de ayrılmaz bir biçimde bağlantılı görmektedir. O'na göre etnosantrizm kavramı, bir etnik grubun üyelerinin kendi gruplarını diğerlerinden üstün kılma ve dışarıdakileri grubun kendi değerlerine ve fikirlerine göre yargılama eğilimine işaret etmektedir. Dolayısıyla etnosantrizm, kişinin kendi etnik grubundan farklı olan davranış ve değer dizgesini yanlış ve kabul edilemez varsayan tutumları beslemektedir (Mair, 1975: 4). Ross Hammond ve Robert Axelrod (2006)'e göre etnosantrizmi, grup içi kayırmacılığı kapsayan evrensel bir tutum ve davranış sendromu olarak değerlendirmektedir. Tutumlar, grup lehine davranış modellerini yücelten ve kendi standartlarını evrensel gören bir dışlayıcı mekanizmaya dönüşebilmesi açısından tehlikelidir. Dahası, grup sınırı olarak gözlemlenebilen etnik, atasal ve ırksal farklılıklar, diğer gruplara 
yönelik bir değerlendirme, tutum ve ölçü aracı haline getirilebilir. Dolayısıyla sosyal kategorileştirme veya sınıflandırma, sosyal davranışların belirleyicisi olabilir (Sumner 1906; Kurzban, Tooby ve Cosmides, 2001). Özellikle sınıflandırma süreci, etnik ve ırksal çizgiler boyunca ilerlemekteyse ardıl sonuçlar kötü ve istikrarlı olmaya daha meyillidir (Kurzban, Tooby ve Cosmides 2001).

Etnosantrizmle ilişkili davranışlar, grup içindeki işbirliğine dayalı ilişkilerin oluşumunu desteklerken, dış gruplarla işbirliğine dayalı ilişkileri asgari seviyede tutmayı desteklemektedir (Levine ve Campbell, 1972). Sumner'e göre grup üyeleri arasında fedakârlık ve sadakata karşılık, grup dışına yönelik nefret ve küçümseme gibi karşılıklı duyguların üretilmesi savaş, yağma ve çatışma gibi radikal durumlarla birlikte çoğalmaktadır. Bunu destekleyen bir argüman olarak Hammond ve Axelrod (2006), grup içi kayırmacılık ile grup dışı düşmanlığı etnosantrizmin en temel bileşenleri olarak ele almıştır. Kinder ve Kam ise etnosantrizmle ilgili dört majör teori öne sürmektedir: ilki, kavramı realistik grup çatışması bağlamında değerlendiren gruplararası çatışmanın sonucu olarak ele alır. İkincisi etnosantrizmi; otoriter kişilik kuramı bağlamında baskı, yansıtma ve yerinden edilmenin psikodinamik süreçlerine konumlandırır. Üçüncüsü sosyal kimliğin ifadesi olarak etnosantrizmin evrensel bir özsaygı özleminden kaynaklandığını iddia eder. Dördüncüsü ise doğal seleksiyona atıfta bulunarak kavramı biyolojik bir adaptasyon ve insan doğasının bir yönü olarak görmektedir (Kinder ve Kam, 2010: 7). Ancak ne şekilde olursa olsun etnik çatışma esnasında ve sonrasında gelişen etnosantrik tutumlar, bir ulusun sosyal yapısına ciddi şekilde zarar verebilecek ve barış içinde bir arada yaşama olasılığını çok uzun süre tehdit edebilecek şiddetli çatışmaları ortaya çıkarabilen ihtimaller yaratır (Gangopadhyay ve Chatterji, 2009). Bu nedenle etnosantrizmi duygu bağlamında detaylı şekilde ele almak sosyal davranış kalıplarını anlamak adına önemlidir.

\section{Bir Tutum Olarak Etnosantrizm: Biliş, Duygu ve Davranışsal Eğilim}

Duygular, siyasi söylem ve medya çerçevelerinde olduğu gibi neredeyse hayatın her alanında belirgin bir şekilde yer alan ve insanların bilgiyi nasıl işlediği üzerinde güçlü etkileri olan özellikler taşımaktadır. Aynı zamanda duygular, gerekli motivasyon olduğunda kolaylıkla eylemle ilişkilendirilir (Frijda, 2004). Dahası duygular, çeşitli uyaranlara yanıt olarak insan davranışını bir şeyi yapmaları veya yapmamaları yönünde motivasyonla yönlendiren güçlü motorlar olarak hizmet etmektedir (Halperin ve Pliskin, 2015). Bölgesel, siyasal veya sosyoekonomik koşullar gibi somut konulardaki anlaşmazlıkların yanında duyguların çatışmalarda anahtar rol oynadığı giderek daha fazla kabul edilmektedir. Bu nedenle politik psikologlar ve çatışma çözümü araştırmacıları, duyguları, anlaşmazlığı sürdürebilen ve çatışma çözümü için etkili rol oynayan bir bağlamda ele almaktadır. Literatürde korku ve güvenlik dürtüsünün şiddet eylemi için temel motivasyon kaynağı olduğu görüşü yaygındır. Çünkü korku, güvenliğe yönelik dikkati artırırken, gücün yakınsamasına bağlı olarak düşmandan kaçmayı/sakınmayı (onur kırıcı, mağdur/savunmasız, korkak) veya çatışma odaklı (tehditkâr, saldırgan) tutumları besleyebilir (Armoudian, 2020: 137). Benzer şekilde öfke de motivasyonel bir kavramdır, enerjiyi harekete geçirir ve bastırılmadığı zaman (özellikle utançla eklemlendiğinde) kişiyi saldırganlığa yöneltebilir (Behrendt ve Ben-Ari, 2012: 1119, Frijda, 2004). Örneğin, Ortadoğu toplumlarında radikal terör örgütlerinin katılımcı/yabancı savaş̧̧ı elde etmesinde öfke ve kızgınlık gibi bastırılmış duyguların etkisi önemlidir. Christopher M. Collins (2012: 24) şöyle der; "Öfke ... hayal kırıklığından kaynaklanan ve genellikle günah keçisi aramak gibi zarar verici eylemler üreten bir duygudur." Bununla birlikte öfkeyle ortaya çıkan 
hor görme davranışı, yıkıcı potansiyeli artıran bir değerlendirme içermektedir (Fischer ve Roseman, 2007).

Klişeleştirme ve önyargı çalışmaları, psikolojide 1920'ler ve 1930'lardan kaynaklanan uzun ve saygıdeğer bir tarihe sahiptir (Katz ve Braly, 1933). Klişeler, algılayıcının bir grup hakkında bilgisini, inançlarını ve beklentilerini içeren bilişsel bir yapıyı ifade etmektedir (Hamilton ve Trolier, 1986: 133). Söz konusu klişeler herhangi bir sosyal grubu hedef alabilir ve klişelerin içerikleri, zaman ve coğrafi bölge boyunca büyük ölçüde değişme eğilimi gösterir. Örneğin, İlandalı, İtalyan, Çinli ve Afrikalı Amerikalıların sosyal klişeleri, ABD tarihi boyunca yaygın olmuş ancak bu klişelerin içeriği zaman içinde önemli şekillerde değişim göstermiştir. Klişeleştirme, her zaman olmasa da, sıklıkla, önyargının eşlik ettiği, bireylerin gruplar hakkındaki düşüncelerinin duygusal yüklü bir yönüdür (Bigler vd, 2006: 42). Oluşturulan klişeler, bilişsel ve davranışsal kanallar aracılığıyla kendilerini yeniden üretirler (Pratto 1999: 198). Insanlar yeni edindikleri bilgi kümelerini, önceki tutumlarını ve dünya görüşlerini doğrulayacak şekillerde süzgeçten geçirerek yorumlarlar (Brandt ve Crawford, 2020). Önyargının "belirli bir gruptaki üyelikleri nedeniyle başkalarına karşı olumsuz bir tutum" olması (Bigler vd, 2006: 42) tüm insan kategorilerini kapsadığında, sosyolojik ve psikolojik patolojiyi besleyebilir ve apartheid gibi haksız ayrımcı uygulamalardan soykırıma kadar değişen davranışlara yol açabilir (Segall, 2016: 113). Ayrıca önyargısı yüksek toplumlar, yeni bilgilerle karşılaştıklarında mevcut inançlarını gözden geçirmeyi reddebilir ve uzlaşma karşıtı bir ilişki modeline devam edebilirler (Levy, 1994).

Dünya görüşü çatışmasının önemli çalışma alanı olarak önyargı; hoşlanmama, insanlıktan çıkarma, sosyal uzaklık ve grup üyelerine yönelik diğer aşağılamaları içerebilir. Bu yaklaşıma göre insanların dünya görüşlerini korumanın bir yolu, dünya görüşüne benzemeyen gruplara ve bireylere karşı önyargıı olmaktır. Ayrıca dünya görüşleri benzemeyen gruplara verilen bu tepkiler, yalnızca belirli bir grubu aşağılamakla kalmaz, aynı zamanda kişinin kendi grubuyla ilişkisini iyileştirebilir ve özsaygısını artırabilir (Brandt ve Crawford, 2020; 3). Bir kişinin bir grubun üyesi olması, her zaman olmasa da çoğu kez klişeleştirme ve önyargı ile ilişkilendirilir. Klişeleştirme ve önyargı genellikle sıkı bir şekilde iç içe geçmiştir. Örneğin önyargılı tutumların bilişsel bileşeninin bir klişe olduğunu savunan yaklaşımlar mevcuttur (Allport, 1954). Goldon Willard Allport (1954) önyargıyı klişeleştirme sürecinin kaçınılmaz bir parçası olarak görmektedir. Önyargının kaçınılmazlığına yönelik temel argüman, klişeler var olduğu sürece önyargının da söz konusu olduğu yönündedir. Billig (1985), bu argümanı indirgemeci bulur. Ona göre kültürel oluşum dışındaki klişe bilgileri birey tarafından inanç ve değer sistemleri ile süzgeçten geçirilir. Böylece birey bu klişeleri ya kabul eder ya da reddeder. Kısaca, bireyler klişeler hakkında bilgi sahibi olabilse de, kişisel inançları klişe ile uyumsuz olabilir ve bunlar otomatik kabul geçerli değildir (Devine, 1989). Ek olarak bir grubun klişesinin kabul edilmesinin o gruba yönelik önyargı anlamına geldiğine dair hiçbir kanıt yoktur. Otomatik süreçler olup olmadığı açısından da bir farklılaştırma yapılabilir. Bu süreçler bellekte tekrarlanan aktivasyon yoluyla geliştirilen bazı çağrışımların kasıtsı veya kendiliğinden aktivasyonunu içerir. Bunlar, bilinçli çaba gerektirmeksizin bir uyarıcıyla meydana gelebilir. Bu süreçlerin bir örneği olarak klişeler gösterilirken (Greenwald ve Banaji, 1995: 6), önyargıların nispeten daha kontrollü ve kasıtlı olduğu varsayılır. Nitekim bu esneklikleri, onları inançlarla uyumlu olarak karar verme, problem çözme ve yeni davranışların başlatılması için özellikle anlamlı kılmaktadır (Devine, 1989). 
Tutum, sosyal deneyim yoluyla bir nesnenin olumlu veya olumsuz olarak benimsenmesi ile oluşan zihinsel ve sinirsel bir hazırlık ve tepki (yanıt verme eğilimi) durumudur (Allport, 1935: 810; Greenwald ve Banaji, 1995). Sosyal davranış olarak tutumlar, genellikle örtük/bilinçsiz şekilde oluşur. Pek çok sosyal gruba yönelik tutum, gelişimin erken dönemlerinde oluşur. Devine (1989), yetişkinler arasında örtük tutumların genellikle çocuklukta edinilen köklü inançlar olduğunu, açık tutumların ise daha yeni, bilinçli olarak oluşturulmuş sosyal grup görüşlerini temsil ettiğini öne sürmüştür. Dolayısıyla sosyal kalıplar ve önyargı, çocukların bilgiyi işleme ve değerlendirmede biliş ve davranışlarını etkiler. Erken dönemde edinilen bu deneyimler nedeniyle sosyal gruplara yönelik tutumlar genellikle değişime oldukça dirençlidir. Yani gelişim aşamasında kazanılan tutumlar, yetişkinlikte gösterilen klişe ve önyargılara zemin hazırlar. Yetişkinlerin sosyal gruplara yönelik örtük tutumlarının çocuklukta oluşan inançları temsil edebileceğini ve bu inançların daha yakın zamanda edinilen inançlara ve bilince göre daha derin, daha yerleşik ve daha az erişilebilir olduğu varsayılmaktadır (Devine, 1989). Dolayısıyla çocuklukta sosyal klişelerin ve önyargıların oluşumunda yer alan süreçleri anlamak aslında bireylerin yaşam boyunca davranışını anlamak için önemlidir (Bigler vd., 2006: 44) Bu noktada "Gelişimsel Gruplararası Teori"nin amacı, çocukların hangi koşullar altında ve ne ölçüde belirli sosyal gruplar hakkında klişe ve önyargılar geliştirdiklerini anlamaktır. Buna göre insanlar doğası gereği klişeler ve grup içi önyargı geliştirmeye yatkın olsalar da (Fishbein, 2002), bu süreçler otomatik veya kaçınılmaz değildir. Ancak tipik olarak bireyler, çocukluk döneminden itibaren kendi iç gruplarını dış gruplarına tercih ederler ve iç gruplarını dış gruplardan daha fazla olumlu özellikleri ile karakterize ederler. Bunun oluşumu için herhangi bir modelleme/öğrenme modeline veya doğruluğu kanıtlanmış kabul edilen davranış dizisine gerek yoktur (Bigler, 2006: 58).

Etnosantrik duyguların kendini gösterdiği bir sosyal ve siyasal yaşamda zayıf/dezavantajlı gruplara suç yükleme davranışı olağandır. Bu bağlamda "Günah Keçisi” kavramına yönelmek önemlidir. Günah keçisi terimi geleneksel olarak Batı araştırmalarında ortaya çıkmıştır. Kudüs'teki Yahudi baş rahip tarafından eski İsrail'de Yom Kippur'da (Kefaret Günü) iki keçiden biri İbrani Tanrısı Yehova için kurbanlık sunusunda, diğeri ise kabilenin günahlarını topluluktan kurtarmak için kullanmıştır. Rahip, kabilenin günahlarını keçiye aktarmak için ellerini hayvanın üzerine koyar ve onu çöle/uçuruma göndererek inanca göre insanları o günahlardan arındırırdı (Ratner vd., 4). Bu kavram başlangıçta kirden arınma ile ilgili belirli bir inanç dizisini sembolize etmiştir. Buna göre ilahi bir gücün istendiğinde ödüllendirip cezalandırabileceği ve sürekli tövbe ve bağışlanma ihtiyacının olduğuna vurgu yaparak cansız nesnelere ve hayvanlara suç ve günahların aktarılabileceğine inanılmıştır. Artık günümüzde günah keçisi yapma davranışı sembolik olmanın ötesine geçmiştir. Çünkü bu kavrama hayatta kalmak, statü korumak gibi amaçlara hizmet eden rasyonel niyet ve nesnel stratejiler eklemlenmiştir (Ratner vd., 9). Dolayısıyla günah keçisi teorisi (Zawadzki, 1948), mevcut kaynaklara yönelik tehditlerin düşmanlık oluşturduğunu ve bu düşmanlığın, zayıf bir dış gruba yönlendirildiğini öne sürer (Esses vd., 1998: 701). Günah keçisi yapma davranışının önyargı ve etnosantrizm ile belirgin bir yakınlığı vardır. Bu noktada insanların, insan gruplarına ve bireylere insan olmayan özellikler ve tanımlamalar atadıkları ve sonucu insandışılaştırmaya kadar giden tehlikeli bir boyuta işaret etmektedir (Brandt ve Crawford, 2020). Bu yaklaşım, anti-eşitlikçi hakları sürdürme niyetiyle ayrımcılık yapmaya istekli olma ve farklı gruplara tolerans eksikliği ile gelen siyasi hoşgörüsüzlük durumlarında zayıf grupların sorumlu tutulmasına yol açabilmektedir (Brandt ve Crawford, 2020: 4). Günah keçisi yapma sürecindeki saldırganlar, genellikle değişiklik kabul etmeyen, hayal kırıklığına karşı kırılgan ve zorluklar için suç atmaya meyilli 
ancak otoriteye bağlı ve onun düzenine itaat etmeye aşırı düşkün kimselerdir. Suç yüklemek için seçtikleri nedensel koşullar genellikle kışkırtıcıdır ve düşmanlığı ve saldırganlığı tetikleyen özellikleri içermektedir (Douglas, 1995). Bu süreçte karmaşık ve düşmanca duygu olarak nefret, "iyiye karşı kötü" çerçeve ve hikayeler aracılığıyla ötekilerini insanlıktan çıkarmaya ve ötekilerinden gelebilecek tehdide karşı güvenlik arayışını canlı tutar (Sternberg, 2005). Suçlama aynı zamanda en yıkıcı duygu olan "nefret"e ilişkin önemli bir değerlendirme olduğundan (Armoudian, 2020: 137) günah keçisi arama, esasen önyargı olgusunun önemli bir belirtecidir. Hitler Almanya'sında soykırımla sonuçlandığı gibi daha yakın zamanlarda Doğu Afrika'da, tek başına sorumlu olamayacakları halde çeşitli ekonomik zorluklardan sorumlu tutulan binlerce Asyalının sınır dışı edilmesi bu kapsamda değerlendirilebilir (Segall, 2016: 121). Dış grupların yerinden edilmiş düşmanlığın hedefi olarak meşrulaştırılması, yüksek ahlaki değerlere sahip olduğunu ve insan hak ve özgürlüklerinin temsilcisi olduğunu iddia eden toplumlarda bile kolaylıkla gerçekleşebilir. Zorluklardan sorumlu oldukları etiketlendikten sonra, onlara yönelik düşmanlığın görünürdeki meşruiyeti artmakta ve onlara karşı ayrımcılık yapmak her zamankinden daha kabul edilebilir bir hal almaktadır (Segall, 2016: 121). Suçu yüklemeye yönelik kolaylaştırıcı zemin hazırlama her zaman gerçek argümanlarla oluşturulmaz. Bazen dış grupların düşmanlığı hak ediyor gibi görünmesini sağlamak o kadar önemli bir hal alır ki, söz konusu gruplara yönelik anlamlandırmalar tamamen hayali olan olumsuz özelliklerle dolu olurlar (Segall, 2016: 123).

\section{Etnosantrik Tutumları Arttıran Faktörler}

Bilişsel psikolojideki çalışmalar, grup sınırlarına dayandırılan ayrımcılık ve kategorileştirmenin bilinçli olduğunu savunmaktadır (Dovidio ve Gaertner 1993, Hammond ve Axelrod, 2006: 927). Bireyleri farklı sosyal gruplara ayırma, iç grup lehine ve dış gruba karşı ayrımcılığa yatkın hale getirme davranışı, sosyal psikolojide kabul edilen bir argümandır (Kurzban, Tooby ve Cosmides 2001). Insan, toplumsal faktörleri kategorize etme ihtiyacına dayalı olarak çevresini onlara karşı "biz"e indirgeyen, grup içi üyelere yönelik sempati ve işbirlikçi yaklaşımın yanında grup dışı üyeleri düşmanca, güvene layık olmayan ve tehlikeli olarak değerlendirmeye iten bu yaklaşım, esasen insanoğlu için rahatsı edici ve zor bir sosyal ortamda grup dışı muhalefete hazır olmayı gerektiren güvenli bir yol arayışıdır. Dolayısıyla etnosantrizm, bir hastalıklı durum veya patolojik bir davranış türü değildir. Dolayısıyla onu anlama ve açıklama için psikodinamik süreçlere ve analizlere de gerek yoktur. Bu kavram aslında bir tür yatkınlığı ifade etmektedir. Onu önyargıdan ayıran özelliklerden biri de budur. Önyargı, bireyin sebepsiz olarak tutumlar (Fishbein, 2002) geliştirdiği sayısız grupla ilişkiliyken, etnosantrizm buna ek (kendi) grup içine yönelik olumlu tutumlarla da ilgilenir (Kinder ve Kam, 2010: 8). Dolayısıyla kavramın odağındaki en önemli unsur, belirli gruplara yönelik tutarlı bir şekilde olumlu ve olumsuz yanıt vermeye yatkınlığı ifade eden ve kişilerin tavır ve davranış niyetlerine öncülük eden "tutum" kavramıdır (Mead, 1972: 156; Capucao, 2010:168). Tutum; grup içine yönelik yani kendi grup veya topluluğuna karşı kültürel değerleri ve milliyetçi duyguları çağırıştırırken, grup dışına yönelik bariz veya örtük bir şekilde dışlayıcı ve küçümseyici yaklaşımlarla kendini gösterebilmektedir. Dave Dean Capucao, tutuma yönelik bu ikili yaklaşımın, pozitif sosyal kimliğin bir gereği olarak temel insan ihtiyacından kaynaklandığını belirtmektedir (Capucao, 2010:168-169).

Bireysel duygular gibi, gruplararası ve kolektif duygular da belirli değerlendirmeler sonucu oluşmakta ve harekete geçme dürtüsünü tetiklemektedir. Grup bağlamında duygular; renkler, bayraklar, üniformalar ve kelimeler gibi anlamlı semboller tarafından canlandırabilir. 
Sembollerle canlandırılan duygular, gruba ait olmanın ne anlama geldiğiyle bütünleşerek davranışları yönlendirme noktasında etkili hale gelmektedir. Grupların etnosantrik yatkınlığını artıran en önemli unsurlardan biri ve hatta belki de en önemlisi geçmişte yaralanmaların bıraktığı izler olarak seçilmiş travmalardır. Bu travmaları taşıyan bireylerin birtakım duygularının açığa çıkması için bu acıları deneyimlemesi de gerekmez. Seçilen travmalar, anlatıların ideolojik bir repertuarı olarak da ortaya çıkabilir ve travmanın geçişi olarak nesilden nesile aktarılabilir. Etnosantrik eğilimleri ortaya çıkaran (veya yeniden üreten) duyguların sosyal ve siyasal ayırt ediciliğini anlamak için ideolojik kaleler olarak seçilmiş travma ve anlatıların etkisine odaklanmak gerekir.

\subsection{Kolektif Bellekte Seçilmiş Travmalar ve Anlatılar}

Geçmiş yaşantıların bıraktığı izler ve travmalar, son on yıllarda uluslararası ilişkilerin önemli bir meselesi olmuştur. Bu noktada politik psikoloji alt disiplininin gerek sosyal psikolojiye ve gerekse siyaset ve uluslararası ilişkilere katkısı önemlidir. Politik Psikoloji, toplumların ya da ulusların birbirleriyle veya liderleriyle olan ilişkilerine odaklanan, sağlıklı ve faydacı bir yöneten ve yönetilen ilişkisini ortaya koymak için birey-toplum-yönetişim üçlemini gözlemleyerek çalışmalar yapılmasını teşvik eden bir alandır. Bu alanlara ek olarak seçmen davranışı, lider davranışı, grup dinamiği ve kitle psikolojisi, iç savaş, soykırım, toplumsal travmalar, terör, baskı grupları, göçmenlik ve entegrasyon alanlarında çalışmalar yürütülmesini de amaçlamaktadır. Burada seçilmiş unsurlar olarak "toplumsal travmalar" saydığımız diğerlerinin (iç savaş, terör, soykırım vs) oluşumunda belirleyici bir master konsept olarak değerlendirilebilir. Travmalarla gelen sekter nefretler, birtakım ayrımcılık modellerini açığa çıkarabilir. Bunlar kendinden farklı olan grup üyelerinin etiketleme, onlara lakap takma, onları resmi süreçlerde görmezden gelme, toplum içinde yok sayma gibi ılımlı ayrımcılık olarak kendini gösterebilir. Bir de aşırı ayrımcılık türleri vardır ki etnik çatışmaların temelinde yatan çoğu zaman bunlardır. Bu ayrımcılık türü sapkınlaştırma, insandışılaştırma/insanlıktan çıkarma ve/veya şeytanlaştırma pratikleri ile karşılıklı öldürme, soykırım, yerinden etme/sürgün gibi şekillerde kendini göstermektedir (Fishbein, 2002).

Kutuplaşmaya ve ardından ayrımcılık ve dışlamaya kadar yaşanan süreçte anlatıların etkisi büyüktür. Anlatıların amacı ise genellikle bir mağduriyete farkındalık yaratmak veya kahramanlığa dikkat çekmektir. Jeffrey Stevenson Murer, Vamık Volkan'dan alıntılayarak psikoloji biliminde "zihinsel temsil" olarak tanımlanan sürecin etnik ve ulusal kimliğin belirleyicisi olduğunu ifade etmektedir (Murer: 2009:114; Volkan: 2013). Herhangi bir toplumun anlatılarını ele aldığımızda, bu anlatıların grup kimliğinin gelişiminde son derece önemli olduğunu görürüz. Bu bağlamda grup anlatıları toplumların kimliklerini geliştirip sürdürdükleri bir zemin hazırlamaktadır (Halbswachs, 2020; Murer, 2009, 2010; Volkan, 2003, 2013, Zarubavel, 1995, 1996). Geçmiş yaşantıların yükünü omuzlayan toplumlar bunların yaralarını sekter nefretler haline dönüştürüp saldırgan yerine geçme haline bürünebilir. Bu duruma "karşıtına dönme" ve/ya da "saldırganla özdeşleşme" de denmektedir. "Sevgili Dostum, hep kurtlar koyunları yemiştir; bu kez koyunlar mı kurtları yiyecek?" Madam Jullien'in Fransız Devrimi sırasında oğluna yazdığı bir mektuptan alınan bu cümle, karşıtına dönmenin özünü içermektedir. Birkaç kurdun birçok koyuna saldırması normal, ancak koyunların etyemez oldukları halde kurtlara saldırması “dönüşüm zamanı"nı göstermektedir. Bu dönüşüm zamanı, çok zamandır savunmasız olanların aniden dişlerini göstermeye başlamasını ifade eden "karşıtına dönme eylemi"dir. Bunun oluşması için tabakalaşmanın net bir biçimde gerçekleşmesi gerekmektedir (Canetti, çv. Aygen, 2014: 60). Her koşulda "karşıtına dönme" 
veya "saldırganla özdeşleşme" kavramlarının mutlaka olacağı anlamına gelmez. Bunun için geçmiş yaşantılar bağlamında travmatik kimliği harekete geçirecek birtakım girişim ve taktiklerin yetkili figürlerce, uygun zamanda ve uygun iletişim kanalıyla ele alınması gerekir. Burada Maria Armoudian (2020)'ın ifade ettiği gibi iletişim aracı ve söylemler olarak "Çerçeve Teorisi" çarpıcıdır. Anlamlar ve değerlendirmelere atfeden çerçeveler; politik ve psikolojik tepkilerin şekillenmesine yardımcı olmaktadır. Bu süreci şu şekilde ifade etmektedir: "Çerçeveler $\rightarrow$ Anlamlar/Değerlendirmeler $\rightarrow$ Duygular ve Sosyal Psikolojik Güçler $\rightarrow$ Eylemler/Davranışlar". Dolayısıyla anlamlar, duygular ve bunların sonucu olarak davranışlar, inançları ve duyguları pekiştirebilecek içselleştirilmiş benzer çerçevelerin inşasına yönelik geribildirim vermektedir (Armoudian, 2020: 138). Sosyal toplumlarda kendi kendine olabileceği gibi medyanın da bu çerçeveleri tekrarlaması ve zaman zaman farklıılılara odaklanarak kışkırtıcı söylemleri, sosyal olarak oluşturulmuş değer ve tutum kalıplarını sanki her gruba bahşedilen verili ve sorgulanamaz/değiştirilemez argümanlar gibi ortaya çıkarmaktadır. Dolayısıyla zaman zaman kişiliksizleştirme de denilen süreç olarak grup üyeliği, kişisel özerkliği zayıflatabilir, klişeleştirmeyi artırabilir ve bireyleri kendi grubuna yönelik Vamık Volkan'ın körü körüne inanç olarak ifade ettiği, kör edici bir inanç ve tutum dizgesine mahkûm edebilir (Volkan, 2005; Armoudian, 2020).

Seçilmiş travma ve zaferleri bulunduran bellek alanında, son yıllarda (özellikle son kırk yılda) kapsamlı çalışmalar yapılmıştır. Kolektif bellek kavramı yani sosyal gruplar tarafından tutulan bellek, uzun bir çatışma geçmişi olan toplumları değerlendirmede önemli bir kavramdır. Kavrama yönelik bir söylem başlatan Maurice Halbwachs'ın çalışmaları, alanın önemli referans noktalarıdır. On yıllardır, çeşitli disiplinlerden araştırmacılar Halbwachs'ın yolunu takip etmektedir. Yapılan çalışmalar göstermektedir ki, ne bireysel ne de grup belleği, insanların içinde yaşadığı sosyal alanlardan bağımsız olarak var olabilir. Ancak hatırlama süreci bağlamsaldır yani yaşanan deneyimlerin kolektif boyutu içinde gerçekleşir (Tint, 2010: 241). Kolektif bellek bir toplumda kendiliğinden gelişmez. Buna göre bellek, pasif bir süreç ya da olguların basit bir şekilde hatırlanması değil, katılımcıların geçmiş deneyimleriyle oluşan seçimsel ve aktif bir süreçtir (Tint, 2002: 242). Sosyal inşacılık, gerçekliği, inanç ve hedeflerin ürettiği anlamların yansıması olarak ele almaktadır. Bu noktada belirli bir toplumun politik ve kültürel amaçlarını ifa etme noktasında belleğin siyasallaşması söz konusu olabilir (Baumeister ve Hastings, 1997; Eber ve Neal, 2001). Volkan (1996, 2003, 2013), "seçilmiş travmalar ve seçilmiş zaferler" kavramları ile toplumların ihtiyaç hissettiklerinde seçici olarak hatırlanan olayları gün yüzüne çıkarmasını ifade etmektedir. Bu unsurlar zaman içerisinde romantikleştirilerek ve efsanevi boyut kazandırılarak Durkheim'in ifade ettiği gibi kitlesel köpürme'nin bir aracısı haline gelebilir (Connerton, 1989; Zerubavel, 1995; Volkan, 1996, 2013). Dolayısıyla anlatı ve gerçek, tarihsel süreçte iç içe geçerek dışlayıcı ve ayrımcı siyasetin bir aracı haline gelebilir. Süregelen çatışmaların ortaya çıkması için, ekonomik çöküşler ve siyasi kayıplar gibi kriz koşulları etkili olsa da tek başlarına yeterli değildir (Armoudian, 2020: 135). Çünkü rasyonel karar verici olarak siyasal aktörler, bu tür sorunları çözmek için işbirliği yapabilir. Aksine, çatışmacı/çatışma odaklı siyasal figürler ise hedeflenen grubu nefret edilen düşmana dönüştürmek için iletişim kanalları aracılığı ile bu olayları kullandığında veya manipüle ettiğinde, sonu soykırıma kadar giden sistematik yoketme ve nefret üretme sürecini başlatabilmektedir (Charny, 1982; Midlarsky, 2005; Staub, 1989). Nitekim yakın tarihte en bilindik örnekler olarak Bosna Hersek ve Ruanda gibi geniş çaplı çatışmaların ve şiddetin ortaya çıkışı bu savı doğrulamaktadır. 


\subsection{Sınırlar ve Bölgesel Sorunlar}

Etnosantrik davranışı teşvik eden önemli bir unsur da hem psikolojik hem de somut bir tanımlayıcı argüman olarak 'sınır'dır. İnsan toplulukları tarafından oluşturulan sınırlar ve yapılar, kimliğimizi ve farklılıklarımızı rahatça yaşayabileceğimiz alanları belirleyen dinamik ve değişken unsurlardır (Barth, 2001: 24). Sonradan eklemlenen yapı ve sınırların işlevi, kimlik adına beklenilenden daha çok anlamlar içerebilir. Dolayısıyla uluslararası bir sınırla bölünmüş bir etnik grubun üyeleri, topluma daha geniş bir dayanışma sağlayan, toprağın sosyal olarak inşa edilmiş yönlerini kontrol eden ve böylece savaşlara yol açan devletlerarası sınır anlaşmazlıklarını getiren potansiyel motivasyona sahip olabilir (Singh, 2002: 83). Sınır, sosyal bir üründür ve zamanla önemi değişebilir (Eriksen, 1993: 38). Önemi değiştiğinde ilişkisel etkileşimde olan azınlık-çoğunluk ilişkisi üzerinde de bu değişimin etkileri görülebilir. Örneğin devlet sınırlarının tekrar çizilmesi ile azınlık çoğunluk olabileceği gibi, motivasyonları artan yeni azınlıkların sisteme dahil olması da mümkündür. Etnik varyasyonla eşgüdümlü olarak devletler, yeni asimilasyon politikaları ile siyasi mekanizmaları da devreye sokarak yönetmeye çalışmaktadır. Her ne kadar asimilasyon politikaları azınlıkların hak elde etmesinde önemli imkanlar sunsa da genellikle itibar kaybı ve değersizlik algısı da yaratmaktadır (Eriksen, 1993: 123).

Sınırlar; verili olmayan, toplumsal olarak inşa edilen coğrafi, bölgesel, sosyal veya kültürel anlamda mekâna gömülü sosyal kavramlardır (Messmer, 2007). Dolayısıyla sınır; sadece bölgesel kavram değildir. Bir ülkenin sınırları içerisindeyken dahi dışarıda kalınabileceği, en iyi dezavantajlı gruplar aracılığı ile anlaşılabilir. Sosyal ve siyasal ortamın anlaşılması için dezavantajlı gruplara yönelik devlet politikaları önemlidir. Ancak alınan önlemler ve uygulanan stratejilerin başarısı, karşı tarafın yani dezavantajlı grup veya azınlıkların bunlara verdiği karşılıkla belirlenebilir. Alfred Hirschman (1970), bu cevapları çıkış, ses getirme ve sadakat olarak ifade etmektedir (Eriksen, 1993: 123; Khmelko vd., 2010: 10). Illk olarak proto-nations olarak tarif edilen bu azınlıklar, devlet politikalarıyla uzlaşmayı asla kabul etmez. İkinci olarak, kendilerini üzerinde uygulanmaya hazırlanan veya uygulanan devlet politikalarını özümsemeyi reddetmeyi tercih eden etnik ayrım kurbanlarıdır. Bu gruplar bir şekilde aktif olarak uzlaşma yolları arayarak asimilasyona direnirler. Son olarak kazanımlar elde etmek, ulus devlette barış̧̧ı bir rol oynamak için devlet ile görüşmelere katılabilen ve kendilerini ifade için yasadışı veya aşırıcı bir tutum sergilememeyi seçmektir. Ancak söz konusu karşılık verme modelleri; taraflar arasında derin polarize olma durumu yaratmayan ve etnik sınırların ve kimliğin yeniden üretimini gerektirmeyen yani ideal olanlardır (Eriksen, 1993: 124-125). Maalesef ki sonuç her zaman ideal ve beklendik bir şekilde gerçekleşmemekte etnik grupların üyeleri etnik terör oluşumlarını inşa edebilecek noktaya kadar gelmekte veya oluşmuş terör gruplarına eklemlenerek gerginliği beslemektedir. Dünyadaki etnik çatışmalar, genellikle etnik grubun üyelerinin bir devlette baskın yönetim mensupları iken ve diğerinde dezavantajlı konumda olduğunda ortaya çıkmaktadır. Ortak etnik kökenli toplulukları barındıran devletlerin etkileşimlerinin muhtemelen çatışmalı olacağı öngörülmektedir. Dolayısıyla devletlerin genel etnik yapısı içinde ulus ötesi etnik bağları ve/veya uzantıları olan bir etnik grubun jeopolitik konumu, devletlerarası çatışma davranışı ve güvenliği için olumsuz sonuçlar üretebilir (Singh, 2002: 84). Ek olarak etnik grupların taleplerinin uluslararasılaşmasının, hem iç seferberliği teşvik edebileceği hem de ikame şikâyetler için uluslararası forumlar oluşturarak devletin dikkatini ve etkinliğini zayıflatabileceği söz konusu olmaktadır. 
Her etnik çatışma şiddet içermek durumunda değildir ve her etnik çatışma kendine has bir özellik sergiler (Rose, 2000). Bazen geçmişten beri süregelen çatışmalar bölgenin karakteristiğini oluşturur. Örneğin, barışa yönelik en büyük tehdidin kalıcı rekabet olduğunu ifade eden Barry Buzan, Güney Asya'nın güvenlik kompleksini Hindistan-Pakistan rekabetine bağlamaktadır. Benzer şekilde bölgesel Arap-Israil rekabeti, bölgedeki barışa yönelik en temel sorunlardan birini teşkil etmektedir (Diehl, 2003: 271). Özellikle bu bölgede, her iki farklı toplum karakteristiğine hitap eden ve paylaşılamayan dini ve kültürel sembollerin varlığı, toplumlar arası rekabeti sürekli kılmaktadır. Somut niteliklerinden ziyade, maddi olmayan nitelikleri için değer verilen toprakları içeren anlaşmazlıklar, barışın tesisini daha zor hale getirmektedir (Diehl, 2003). Farklı bölgelerin farklı boyutlarda tehditlerle karşılaşması da doğaldır. Örneğin Avrupa'nın bölgesel çatışma yönetimindeki başarısı Ortadoğu ve Güney Asya gibi bölgelere nazaran daha fazladır. Çünkü burada tehditler daha sınırlı/düşük düzeylidir. Nitekim sınırlı tehditlerle başa çıkma noktasında başarılı devlet argümanı ortaya çıkmaktadır (Diehl, 2003: 279). Özellikle etnik çatışmalara yönelik başarısız devlet olma durumu, bazen komşu devletlerin çeşitli müdahalelerine izin vermektedir. Örneğin, Soğuk Savaş sırasında iki süper gücün vekalet savaşlarından olan Kongo'daki sivil çatışmaya komşu devletler hem hizipleri desteklemek hem de onlara karşı savaşmak için destek göndermiştir. Ayrıca komşu devletlerin müdahaleleri her zaman açık ve doğrudan olmayabilir. Örneğin, Keşmir meselesinde Pakistan'da Afganistan'ın Taliban yapılanmasının teşvikleri (silah ve malzeme aktarımı) tarafların pozisyonunu etkilemiştir (Diehl, 2003: 272).

\subsection{Lider-İzleyici Etkileşiminin Önemi}

Toplumda bir arada yaşamayı engelleyen etnosantrik davranışların meşru kabul edilmesinde lider-izleyici etkileşiminin etkisi oldukça önemlidir. Hele ki grup üyeleri grup sınırlarını etnik çizgiler üzerinden belirlemeye elverişli ise ve siyasal ortamda güvensizlik varsa bu etki daha belirgindir. Grubun olduğu yerde liderliğin olması olağan bir durumdur. Birinin lider olması, diğer insanların hedeflerinin ve eylemlerinin o kişiden etkilendiği anlamına da gelir. Dolayısıyla istediklerini yaptırmak veya yaptıklarını ve yapacaklarını kabul ettirmek noktasında liderliği anlamak, insanların nasıl ve neden belirli diğerlerini takip ettiklerini anlamayı gerektirmektedir (Brown ve Pehrson, 2019: 100). Geleneksel uluslararası ilişkiler disiplini dünya politikasında önemli rol üstlenen liderlerin kişisel özelliklerini arka plana iterek daha ziyade onların rol aldıkları sisteme, yapıya ve kurumlara odaklanmıştır. Özellikle Kenneth Waltz'ın (1959) "Man, the State and War" adlı eserinin yayınlanmasından bu yana, araştırmacılar güç dengesi gibi yapısal faktörleri ve iç siyasi kurumlar gibi birim düzeyindeki faktörleri liderin siyasetteki rolünden ve bireysel düzeydeki farklılığın dış politikada rol oynaması olasılığından çok daha fazla vurgulamışlardır. Ancak son yıllarda devlet düzeyli bir bakış açısının yanında lider düzeyini de uluslararası politika modellerinde analiz eden yeni bir araştırma dalgası oluşmuştur (Croco 2011; Chiozza ve Goemans, 2011; Horowitz ve Starn 2014; Horowitz ve Fuhrmann, 2018: 2072).

Giacomo Chiozza ve Hein E. Goemans (2011: 3), Uluslararası illişkiler'in geleneksel akımlarında liderlerin neden ve ne zaman ülkelerini savaşa sokmaya karar verdiklerini anlama ve açıklama çabalarının az olma nedenlerine vurgu yapmaktadır. Araştırmacılar kapitalizm, güvenlik ikilemi ve çok kutupluluk gibi sistemsel güçlerin sonucu olarak savaşı açıklayan teorilerde liderlere yönelik ilginin geri planda kaldığını ve aslında neredeyse tüm savaşların liderlerin bilinçli kararları nedeniyle başladığını öne sürerler. Aslında Uluslarararası ílişkiler alanının bir disiplin olmadan önce oluşum felsefesinde dahi ahlaklı bir lidere yapılan atıflar 
azımsanmayacak boyuttadır. Niccolo Machievelli'nin "The Prince" adlı eserinde devlet adamlarının güç maksimizasyonuna dair sunduğu pratikler ve yine Thucydides'in "Peloponez Savaşları"nda devlet adamı figürü, klasik realist teorinin de merkez ilgisinde olmuştur. Bununla birlikte modern Uluslararası iliş̧kiler alanının ortaya çıkışı da uluslararası siyasette iktidara yaptığı vurguyla ünlü olan Hans Morgenthau'nun "Politics among Nations"çalışmasının 1948'de yayınlanmasıyla olmuştur (Horowitz ve Fuhrmann, 2018: 2074). Ancak takip eden literatürde liderler, kişisel özelliklerinden bağımsız ve işlevsel olarak özdeş bir şekilde değerlendirilmiştir (Horowitz vd., 2018: 2181). Geleneksel uluslararası ilişkiler, liderin kişisel özelliklerinden ziyade siyasi kurumların liderlerin seçimlerini nasıl şekillendirdiğine ve politika seçimlerini nasıl etkilediğine odaklanmıştır (Horowitz ve Starn, 2014: 527).

Peki lider toplumsal motivasyonları anlama ve anlamlandırmada neden önemlidir? Literatürde izleyicilerin, liderlerini ebeveyn figürleri olarak ele alma ve liderlerle ilişkilerini çocuk-ebeveyn koşullarında zihinsel olarak inşa etme eğilimi vardır. Yani izleyiciler, liderleri onay alma ihtiyacı hissettikleri insanlar olarak görürler ve bu yatkınlık, sembolik statü diyebileceğimiz bir iktidarı kaynağı oluşturur. Bu kaynak liderlere, takipçileriyle olan kişiler arası ilişkileri ve nihayetinde takipçilerin benimsediği inanç sistemleri üzerinde bir ölçüde kontrol sağlar (Sankowsky, 1995: 59). Burada inanç sistemleri ile kastedilen geçmişin, bugünün ve geleceğin bir dizi imajından oluşan dünya hakkında sahip olduğu birikmiş tüm bilgileri içeren yönetilemez bir mercek seti olarak düşünülebilir (Holsti, 1989). Liderler, demokratik toplumlarda savaş eylemleri için halk desteği aradığında, bu inanç sistemleri içerisindeki kontrolünü, çatışma çözümü veya mevcut seçenekler hakkındaki tutumları etkilemek veya manipüle etmek için kullanılır (McAlister, 2001: 87). Literatürde birbirinin yerine de kullanılan "dönüşümcü" ve "karizmatik" liderlik, bir çeşit "referans gücü" olarak değerlendirilebilir. Bu tür liderler, sadece mevcut arzu ve ihtiyaçlara hitap etmek yerine insanlara kendini gerçekleştirme gibi daha yüksek seviyeli motivasyonlara yönelik ilham vermelerinden dolayı "dönüşümlü" olarak adlandırılırlar (Burns, 1978). Bu tanıma büyülü denebilen bir nitelik olarak anlaşılan ve takipçilerin belirli bir mesaj veya vizyonla başkalarını heyecanlandırmasını sağlayan karizma kavramı etkilidir (Brown ve Pehrson, 2019: 102).

Politik psikolojideki temel teorik yaklaşımlar da herhangi bir sosyal fenomen analizinde iktidarın önemine değinmektedir. Nitekim tarih, bizlere liderin zekasının, mizacının, geçmişinin, önyargılarının ve diğer psikolojik faktörlerinin bir çatışma sırasında ve çözümünde ne denli önemli faktör olduğunu göstermiştir. Savaş zamanında benzer tehditlere yönelik lider davranışlarında önemli farklılıklar bulunmaktadır. Bazıları çatışma esnasında daha saldırgan tavır alırken, bazıları da daha kolay teslim olmaktadır. Genellikle liderlerin son hedefini garantileyinceye kadar savaşması bilindik iken bazıları zaferden yoksun kalırlar ve hatta savaş öncesi statükodan daha azına bile razı olabilirler. Bunun gerçekleşmesi için mutlaka farklı siyasi yapılanmanın (yönetimsel farklılıklar, rejim tipi vs.) olması da gerekmez. Benzer rejimlere sahip ülkelerin liderleri arasında da farklı davranışlar görülebilmektedir. Bazı demokratik liderler popüler olmayan çatışmaları sona erdirerek kamuoyunun tepkisine boyun eğerken, bazısı da kamuoyunun muhalefetine rağmen savaşları devam ettirmekte ısrarcı olmaktadır. Benzer şekilde, bazı otokratik liderler, yenilgiye zorlanıncaya kadar savaşır, bazısı da savaşları sona erdirmek için isteyerek silahlarını bırakabilir (Croco, 2011: 457). Bu bağlamda liderin karar ve politikaları ile şiddetli çatışmalar arasında karşılıklı geri bildirimler olduğu söylenebilir. Bazı bireysel düzeydeki öz nitelikler ve deneyimler bir liderin askeri gücün 
etkinliği hakkındaki inançlarını da etkilemektedir (Kennedy, 2011; Horowitz ve Starn, 2014). $\mathrm{Bu}$ inançlar, ortaya çıkardıkları zorlayıcı tehditlerin risklerini ve sonuçlarını da şekillendirmektedir. Yani liderin deneyimleri ve dünya görüşü çatışma motivasyonunu etkilemektedir. Mesela ordu ile deneyimleri ve güç kullanımı kanaatleri, liderlerin silahlı çatışmanın maliyetlerini, faydalarını ve risklerini değerlendirme şeklini etkilemektedir (Sechser, 2004). Amprik araştırmalar göstermektedir ki savaş deneyimi olmayan askeri kariyere sahip liderler, askeri güç kullanımı konusunda aşırı iyimser olma eğilimindedir. Bu nedenle bu liderler çok sık krize girmeye ve yetenekli düşmanlara karşı askeri anlaşmazlıkları başlatmaya daha yatkındır. Başka bir deyişle militarize edilmiş anlaşmazlıkları ve savaşları başlatma olasılığı en yüksek olan liderlerin, askerlik hizmeti vardır, ancak savaş deneyimi yoktur (Horowitz ve Fuhrmann, 2018; Horowitz vd 2018: 2182). Kayzer II. Wilhelm ve Muammar Kaddafi gibi liderler, göreve geldiklerinde ordu kullanımına ve askerlik hizmetine aşina, ancak riskler ve sonuçları öngörebileceği savaş deneyiminden yoksun siyasetçilerdi (Horowitz ve Starn, 2014: 528). Sonuç olarak kişisel tutum ve deneyimleri ne olursa olsun, bir siyasi lider, çok sayıda grup üyesi üzerinde önemli bir kontrolü nasıl elinde tutabileceğini iyi bilirse, topluluğu etkili bir şekilde şiddetli etnik çatışmaların tarafları olabilecek rakip gruplara bölebilir (Gangopadhyay ve Chatter, 2009: 58).

\section{Etnik Çatışmalarda Barış İnşa Süreci}

Her ne kadar maliyetli, acı verici ve etkisiz bir yöntem olsa da insanın olduğu yerde genellikle kaçınılmaz olarak çatışma da vardır (Zartman, 2007). Genellikle güç, çatışmanın şanslı tarafını belirlemektedir. Güç çekişmelerinde kazan-kaybet çekişmesinin yarattığı güvensizlik, taraflar arası ilişkiye zarar vermektedir. Bunun yerine çatışma çözümleri yaklaşımları ve barış araştırmaları, çatışan taraflar arasında önleyici diplomasinin yanında "kazan-kazan" durumunu oluşturacak çalışmalar öne sürmektedir. Böylelikle çatışma çözümünde oyun teorisinin dört sonucundan memnuniyet verici/tatmin edici sadece biri gerçekleştirilmek istenir. Aksi halde, sonucun sıfır toplam olduğu veya daha da kötüsü negatif bir toplam olduğu (yani işbirlikçi olmayan oyun teorisinin standart modelleri durumlarında) çatışma muhtemelen tırmanacaktır (Eggert ve Falzon, 2018: 3). Barış çalışmaları güvensizlik sorununa birim düzeyinde yaklaşarak, devletleri, uluslararası ilişkiler oyununda kendi avantajlarını en üst düzeye çıkaracak şekilde oynamaya yönlendirerek çözmeye çalışmaktadır (Buzan, 1984: 112). Buna ek olarak son yirmi yılda duyguların savaş ve barışa ilişkin bireysel ve kolektif inançları, tutumları ve davranışları nasıl etkilediği barış çalışmalarının ilgi odağında olmuştur. Stephane Baele ve arkadaşlarına göre duygu, tüm büyük çatışmaların merkezinde yer almış ancak bu gerçek uzun zamandır göz ardı edilmiştir. Son zamanlarda yapılan çalışmalar bu açığı kapatmak için çaba sarf etmektedir (Baele vd., 2016: 719). Örneğin güvensizlik ve korku, Sri Lanka'da Singala ve Tamiller; Eski Yugoslavya'daki Sırplar ve Boşnaklar; Filistin'deki Araplar ve Yahudiler; Ruanda'da Hutu ve Tutsiler gibi dünyanın çeşitli bölgelerinde etnik çatışmalara karışan büyük kimlik grupları arasındaki ilişkileri karakterize etmektedir (McDoom, 2012: 119).

Çatışma kaçınılmaz olduğu için, toplum bireyleri bazen çatışmaların sonuçlarıyla başa çıkmaya çalışırken beklenmedik savunma mekanizmalarına girebilmektedir (Egger ve Falzon, 2018: 24). Diğer bir deyişle, mağduriyet kaynaklı önyargı ve düşmanlık olarak gelişen duygular ve fark edilmeden geliştirilen tutumlar, bir savunma mekanizmasının parçası olabilir. Böylece gruplar arası ilişkilerin sıradan ve dinamik bir özelliği olarak anlaşmazlıklar, daha keskin veya uzun süren ve çözüme direnen sosyal çatışmalar olarak müzmin çatışma (intractable conflict) 
halini alabilir. Geçmişte yaşanan etnik çatışmanın göze çarpan olayları üzerine algılananlar, bu tür çatışmalarda referans noktası olarak hizmet edebilir (Bar-Tal, 2001). Müzmin çatışma, uzun süredir devam eden, çözüme direnen (Putnam ve Wondelleck, 2003), uzlaşmazlık olarak nitelendirilebilen ve doğası gereği döngüsel olarak görülen son derece karmaşık bir çatışma modeli olarak görülmektedir. Bu model çatışma, tamamlanmamış yas, kalıplaşmış düşünce ve davranış tekrarlarının sürdürülmesine neden olur ve uzlaşmaya izin vermez. Dolayısıyla nostaljik bir kayıp duygusu, etnik şiddetin oluşumunda güçlü bir söylem olabilir (Ray, 1999; Volkan, 2011, 2003, 2013). Böylece çatışmalar müzmin hale gelir. Müzmin çatışmalar, etnik kimlik üzerinden ilerlediğinde kimliği sıfır toplamlı hale getirebilen bir hal almaktadır (Kelman, 1999, 2006; Wondolleck vd., 2003; Zartman, 2005). Yani bu tür çatışmalarda taraflar kimliklerini, diğer grup/grupların olumsuzlamasına dayanacak şekilde tanımlar. Bu anlamda kimlikler birbirine olumsuz olarak bağlıdır (Kelman, 1999, 2006; Wondolleck vd. 2003). Bu bağlamda tarafların birbirini kimlikliksizleştirme çabaları ve kimliğin de müzmin çatışmaları karakterize etmesi nedeniyle literatürde bu tür çatışmalara "müzmin kimlik çatışmaları" da denmektedir (Lewicki vd., 2003).

Tarihsel süreçte etnik çatışmalar, devletin iç meseleleri ve egemenlik alanları olarak değerlendirilmiştir. Bu anlayış, hem sistemin tek kutuplu olarak değişmesi ile hem de egemenlik ve kimlik gibi birtakım kavramların anlamının genişlemesi ile değişim göstermiştir. Dolayısıyla etnik çatışmalar kendiliğinden veya bir anda ortaya çıkan çatışma türleri olmadığı gibi sadece çatışan grupların da meselesi değildir (Kelman, 1997; Mann çev. Doğan, 2012: 30). Toplumlararası mesele olarak etnik çatışmaları teşvik eden duygusal, tarihsel, yapısal birçok faktör etkin rol oynamaktadır. Nitekim, diplomatik çabalar, son on yıllarda bölge dışından üçüncü tarafları da çatışan tarafların ilişkilerine dahil etmiştir. Hatta etnik çatışmalar, uluslararası ortamın çözüm arayışı içerisine girdiğinden 'uluslararası güvenlik meselesi' halini almıştır. Uluslararası güvenlik, çatışma yönetimi ile ve çatışma yönetimi de her şeyden önce diplomasi ve müzakere yoluyla sağlanmaktadır. İstenildiği kadar pahalı askeri donanım tesis edilsin uzlaşmayı sağlayacak şekilde tarafların karşı karşıya geldiği etkili bir diplomasi tercih edilmedikçe çatışmayı sonlandıracak kararların kendiliğinden ortaya çıkması beklenemez (Zartman, 2008). Bu anlamda son on yıllarda barış ve çatışma ekonomisi ve siyaseti üzerine literatür, önemli bir bilimsel ilerleme kaydetmiştir. Bu süreçte "Barış Çalışmaları" adı verilen yeni bir sosyal bilim disiplini ortaya çıkmıştır. Barış Çalışmaları'nın amacı, sosyal ve doğal bilimlerin çeşitli alanlarından araçları, yöntemleri ve teorik çerçeveleri kullanarak bunları geliştirmek ve uluslararası ilişkilere entegre etmektir (Gangopadhyay ve Chatterji, 2009). Dahası barış çalışmaları perspektifi, devletlerarası şiddet ve güvensizlik sorununun nedenlerini ortadan kaldırarak sorunları çözmeye yöneliktir (Buzan, 1984).

Soğuk savaş sonrası manzaranın trajik bir parçası olan etnik çatışmalar, esasen bir grubun "diğerine göre" statüsüne ilişkin endişelerin sonucudur (Horowitz, 2000; Rose, 2000; McDoom, 2012). Donald Horowitz, endişe duygusunu, algıları değiştiren ve olağan tehditlere aşırı tepkiler üreten bir duygu türü olarak ele almaktadır. Bu noktada etnik gruplar için temel tehdit, yok olma korkusu olarak ortaya çıkmaktadır (Horowitz, 2000). Etnik çatışmalarda tarafların geçmiş yaşantıları ve kendilerine has kültürel birikimleri, grup kimliğini ve grupluk sınırının belirleyicileri olarak birtakım roller üstlenmektedir. Eski Sırbistan Cumhurbaşkanı Slobodon Miloseviç "etnik çatışmaya geçmişte yaşanan gelecek korkusu" neden oluyor derken aslında duyguların gruplararası ilişkilerde belirleyiciliğini ortaya koyan önemli bir tespit yapmıştır (Singh, 2002: 82). Bu bağlamda topluluklar, genellikle iç savaş ve terör eylemleri 
sonucu oluşan travmanın üstesinden gelmekte başarısız olmaktadır. Bunun kaynağı, anlam arayışı ve rahatlama hissi ihtiyacıyla travma sonrası insanların felaketin ardından nesiller boyunca yaralanma hikayeleri ve yaralanma fantezilerinin iç içe geçtiği anlatılarında yatmaktadır. Maalesef ortaya çıkan anlatılar toplumsal ve zihinsel bir rahatlama getirse de hem var olan ızdırabı uzatan hem de sonraki ızdırabı başlatan unsurları inşa etmektedir. Özellikle toplumsal duygu devinimlerini ortaya çıkaran üç tip anlatı bu noktada önemlidir: geleneksel kahraman asker anlatıları, diğerinin şeytanlaştırılmasına yol açan iyiye karşı kötü anlatılar ve son olarak intikam alma davranışlarını harekete geçiren kurtarıcı şiddet anlatısıdır (Bulutgil, 2018: 1140; Eber ve Neal, 2001; Schick, 2011: 1842-1843). Devam eden travmanın bir başka örneği de iyileşmemiş travmanın genel olarak aktarıldığı yerdir. Travmanın bu türden nesiller arası aktarımı, gelecek neslin önceki nesillerin travmasını bilip bilmediğine bakılmaksızın gerçekleşebilir. Kişilerin gördükleri ve duyduklarını anlamlandırdıkları (bilişsel ve duyuşsal) ve deneyimleyerek ve gözlemleyerek empati yapabildikleri (sosyal öğrenme) ikincil travma, travma faillerinin başkalarına zarar vermenin ardından acı çektiği katılım kaynaklı travmayı ifade etmektedir (Schick, 2011: 1841). Dolayısıyla toplumsal çatışma içinde hatıralar ve grup anlatıları, genellikle bilginin basitçe aktarılmasından daha fazlasını temsil etmektedir. Bu toplumlarda, sadece bellekler ve objektif gerçekler değil bunlarla ilişkili değerler, duygular ve inançlar da aktarılmaktadır. Belleğin bu şekilde subjektif aktarımı için kullanılan çeşitli teknikler arasında kitlesel ruminasyon bağlamında ihmal, uydurma, abartma, nedensel bağlantıların koparılması, düşmanın veya dışsal koşulların suçlanması yer almaktadır (Eber ve Neal, 2001; Tint, 2002: 243).

Çatışma çözümüne yönelik arabuluculuk ve müzakereler geçmişe değinmez, bunun yerine şimdiki zaman ve gelecekle başa çıkmak için stratejilere ve yaklaşımlara odaklanmaktadır (Tint, 2002: 247). Mevcut arabuluculuk düşüncelerinin çoğu arabuluculuğun ileriye dönük bir süreç olduğunu, geçmişteki olumsuz veya zararlı olayların suçunu aramayan ve tarafların çıkarları için acil sorunları çözmeye çalışan bir süreç olduğunu varsaymaktadır. Buna göre ilişkiler geleceğe yönelik olumlu bir şekilde değerlendirilmektedir. Ancak çatışma üç zaman diliminin de meselesidir ve güven inşası için her dönemin açtığı yaralarla ilgilenmek gerekir. Bush ve Folger (1994) arabuluculuk ve çatışma çözümüne yönelik dikkatimizi dönüştürücü süreçlerin temeli olarak "kabul etme ve tanıma"ya yönlendirmektedir. Bu bağlamda geçmiş, empatiyle (yani diğerinin bakış açısından kabul edip tanıma ile) çatışma çözümünün dönüştürücü boyutunun unsuru olarak ele alınmalıdır. Dolayısıyla geçmişe yönelik davayı sürdürmek değil, davanın gerçeğiyle yaşama yeteneği geliştirilerek yani tarihi bağlamı belirleyici olarak değil sadece göz önünde bulundurarak toplumsal huzur ve barış tesisi sağlanabilir. Çatışan taraflar arasında silahsızlanma ve silahların kontrolü, temel barış politikaları olarak öne çıksa da (Buzan, 1984), çatışmanın dinamiğini besleyen asıl nedenler algısal nedenlerdir). Mısır Devlet Başkanı Enver Sedat'ın 9 Kasım 1977'de Mısır Halk Meclisi'nde yaptığı konuşmasında İsrail ile Araplar arasındaki sorunun önemli kısmının psikolojik olduğunu ileri sürmüş ve uluslararası politika yaklaşımını bu görüşe göre şekillendirmiştir (Arıboğan, 2020: 38-57). Arap-issail toplumları gibi geçmişi olan toplumlarda karşılıklı duygu üretimi ve psikolojik olarak örülmüş tutumlar, barış çalışmalarının önünde önemli engellerdir. Çünkü suçluluk, utanç, mağduriyet ve öfke gibi duygusal faktörler uyuşmazlık çözümü ve arabuluculuk girişimlerinde derecesi saptanamayan unsurlardır (Behrendt ve Ben-Ari, 2012). Duyguların siyaset sahnesindeki önemi, sadece çatışma yönetimi ve barış çalışmaları açısından değil yabancı savaşçılar ve çocuk askerler fenomenleri gibi tali sorun alanlarını besleyen 'terör ile mücadele'de de belirgindir (Haer ve Böhmelt, 2017). 
1960'lı yıllardan itibaren her ne kadar uluslararası ortam barış inşası fikrine çok açık değilse de çatışmalar sonrası "Travma Sonrası Stres Bozukluğu (TSSB)"na yönelik terapötik yaklaşıma doğru bir geçişin olduğu görülmektedir. Özellikle Amerika Birleşik Devletleri'nde yaşanan 11 Eylül 2001 terör saldırıları gibi travmatik olaylar, bireysel, topluluk ve ulusal düzeylerde çatışma senaryolarının duygusal zemini olmuştur (Pupavac, 2002, 2004; Tint, 2010: 240, Arıboğan, 2020: 56). Özellikle son yirmi yılda savaştan etkilenen toplulukların duygusal durumu, uluslararası politika yapıcılar ve analistleri için merkezi bir ilgi ve endişe odağı haline gelmiştir (Pupavac, 2004: 154). Ruanda, Çeçenya, Bosna ve Kosova'daki sistematik şiddet ve terör olayları gibi çatışma türleri genellikle çok fazla duygu ürettiğinden bu duygularla başa çıkma uluslararası bir mesele olmuştur (Egger ve Falzon, 2018: 25). Uluslararası aktör ve kuruluşlarca toplumların psikolojisi ele alınarak oluşturulan güvenlik paradigması, devlet temelli uluslararası güvenlik sisteminden inanç, duygu ve davranışlarıyla insan güvenliğine yönelen bir anlayışa doğru kaymıştır (Duffield, 2001; Pupavac, 2004: 152). UNICEF ve DSÖ (Dünya Sağlık Örgütü) gibi yardım kuruluşları raporlarında, savaştan etkilenen toplumların travmatize olacağı ve travma sonrası stres bozukluğuna (TSSB) maruz kalacağı varsayımları hakimdir (Pupavac, 2002; 2004). İnsan güvenliği fikirlerine dayanan ve yoksulluğun ve savunmasızığın azaltılmasının etkilerini iyileştiren yardım, son on yıllarda siyasal etkilerini daha çok hissettirmekte ve doğrudan güvenlikle ilişkilendirilmektedir (Pupavac, 2002; Duffield, 2002). Siyasi aktörler, farklı kültürlerin ve inançların zorluklara farklı tepki verebileceğini kabul etseler bile, yine de bir savaştaki mültecilerin veya savaş sonrası toplumların travmatize edilmesi gerektiği varsayımını otomatik kabul ederler. Psikososyal çalışma, uluslararası insani müdahalelerin temel bir yönü olmuştur (Pupavac, 2002: 490). Bu çalışmaya göre, etnik nefretin kökenleri "travmatik belleğin güçlü rezervuarında" aranmaktadır. Uluslararası travma uzmanlarına göre travma, "istikrarlı ve üretken bir ortama" dönüşü engellemektedir (Pupavac, 2002: 500). Bunun yanında uluslararası yardım programları, milislerin harekete geçirilmesine ve güçlendirilmesine dolaylı da olsa katkıda bulunabilmektedir. Özellikle dış yardımın mevcut tek kaynak olduğu ortamlarda bu etki daha belirgindir (Lederach, 1997). 1990'ların ilk yarısında Somali örneğinde, bu durum açıkça görülmektedir. Yardım çabalarının ulaşmaması için milisler güvenli sayılabilecek bölgelerde de tehdit unsuru olmuştur. Bu nedenle yardım teslimatlarının gerçekleşmesi için dahi güvenlik koridorları oluşturulmuştur. John Paul Lederach (1997; 91), bu duruma "yarayı saracak eli korumak için, yaralanmanın nedenlerini daha da kötüleştiriyoruz" diyerek sorunun döngüsel doğasına atıfta bulunmaktadır. Ayrıca sahada edindiği deneyimlerden yola çıkarak Lederach (1997), bir krizi yatıştırmaya veya barışı yeniden tesis etmeye yönelik çabaların sonunda barışı tesis etmek için önemli ekonomik desteğin söz konusu olduğunu ve bu durumun uygulamada birtakım problemlerle karşılaşıldığını ifade etmektedir. Ekonomik kalkınmanın, çatışmaların etkili bir şekilde çözülmesinin ve kalıcı barış için bir ön koşul olduğu şeklindeki fikirleri destekleyen, eleştiren ve tamamlayan bol miktarda çalışma ortaya çıkmışsa da ekonomik müdahaleye rağmen dünyanın bazı bölgelerinde hala bitmeyen şiddet ve çatışmalar yaşanmaktadır (Gangopadhyay ve Chatterji, 2009).

Toplumlar için yoksulluk ile travmatik iyileşme eşgüdümlü değildir, çünkü psikolojik refah ekonomik refahtan bağımsızdır (Pender, 2002). Dolayısıyla uluslararası terapötik müdahale ve yardımlar; küresel, yerel ve psişik sonuçlarla da ilişkilidir (Duffield, 2002: 308). Sadece masada gerçekleştirilen barış, barış içinde bir arada yaşamayı da garantilemez. Bunun örneğini Balkanlarda Bosna Hersek'in Dayton Anlaşması'ndan sonra beliren istikrarsız siyasal ortamda ve 1980 ve 1990 'larda şiddetli iç savaş yaşadıktan sonra barış yapan ancak isyancı eylemlerin 
yerini şiddet içeren suçların aldığı Orta Amerika ülkesi Guatemala'da görülebilir (Gangopadhyay ve Chatterji, 2009). Yine İsrail-Filistin meselelerinde de görüldüğü üzere düşmanca anlatılar, stereotipler ve varoluşsal korkular barış sürecinin önünde aşılması güç engellerdir (Kaufman, 2009: 403). Örneklerini rahatlıkla çoğaltabileceğimiz bu gibi durumlar, çatışmaların çözümünün kâğıt üzerinde değil, duygular ve kültürler üzerinden anlaşılmaya çalışılmasının önemini vurgulamaktadır. Özetle kalıcı barış yaratmak için köprüler inşa etmede, ekonomik araçlara ek olarak toplumların birbirine karşı tolerans seviyesini artıran tali yöntemlere ihtiyaç vardır. Bu durum özellikle etnik çatışmalar sonrası barış girişimlerinde önemlidir. Savaş sonrası sosyal atmosferin rehabilitesi için savaş süresi, savaşın sonucu ve kayıplar gibi savaşa dair özellikler belirleyicidir (Doyle ve Sambanis, 2006; Toft, 2010; Gurses ve Rost; 2013). Şüphesiz ki grup büyüklüğü, grup koşulları, savaş sonucu ve savaş süresi savaşın tekrarı risklerini etkilemektedir, ancak bunlar etnosantrik tutumlarla baş gösteren siyasi ayrımcılık için olanlar kadar güçlü değildir (Gürses ve Rost, 2013: 470).

Etnik bir savaştan sonra barışı yeniden inşa etmenin zor olduğuna dair genel bir kanı vardır (Gürses ve Rost, 2013: 470). Barış çalışmalarında etnik çatışmalara yönelik temel hedeflerden biri, taraflar arasında kutuplaşmayı önlemektir. Kutuplaşmayı önleme ve barışı koruma için, çatışmanın tüm taraflarının barışı istemesi, barışı koruma misyonuna rıza göstermesi ve bu talepleri doğrultusunda gerektiğinde iş birliği yapması gerekmektedir. Bunun için uluslararası toplum da harekete geçmek için güçlü bir şekilde motive edilmelidir (Kaufman, 1996). Bu nedenle uluslararası toplum bu hedefe ulaşmak için genellikle uluslararası güvenlik gücünü ve etnikler arası bir arada yaşamayı zorlayan sivil yönetimin varlığını kullanmaktadır. Ancak siyaset yapıcılar tarafından etnik meseleler, her bölgede aynı hassasiyette değerlendirilmemektedir. Dahası hükümetlerin barış çabalarına yaklaşımı farklıık gösterebilmektedir. Örneğin barışı koruma girişimlerinde Makedon hükümeti, Makedonya'daki bir çatışmanın daha geniş bir Balkan savaşına dönüşebileceğinden korkarak önleyici adımlar atmışken, 1991 yılı Hırvatistan hükümeti ülkenin istikrara kavuşması için aynı motivasyona sahip olmamıştır (Kaufman, 2010). Belirtmek gerekir ki, barışı mümkün kılmada hükümet ve siyasi liderler, merkezi bir rol oynamaktadır. Hükümet, muhalefet tarafında savaşta yer alan bir etnik grubun siyasi ve ekonomik haklarına saygı duyar, azınlık etnik bir gruba asgari siyasi katılımı garanti altına alır ise savaş sonrası barışı koruma (aksine nazaran) daha başarılı şekilde yürütülebilir ve savaşın tekrarlama riski azaltılabilir. Aksine, devlet politikaları ve/veya liderin tutumları etnik gruba politik ve ekonomik olarak ayrımcılık yaparsa, toplum içerisinde olumsuz duygular ve etnosantrik eğilimler baş gösterebilir ve savaşın (veya değişik derecelerde çatışmaların) tekrarlama riski artabilir (Gürses ve Rost, 2013). 1989 yılında Hırvatistan'da gerçekleştirilen müzakerelerin etkili bir sonuç vermemesi, büyük ölçüde Sırpları tek taraflı olarak azınlık statüsüne indirme hususunda ayrımcı ve ısrarcı tavırlarından ve Tudjman'ın Hırvatistan'daki Krajine Sırplarına yönelik taleplerini göz önünde bulundurmamasından kaynaklanmıştır (Rose, 2000: 36; Roe, 2007). Yukarıda değinildiği gibi grup anlatılarının siyasal bir zemin oluşturduğu ve belirli davranış ve tutum dizgesini yerleşikleştirdiği ortamda, barış için gerekli motivasyondan bahsedilememektedir. Stuart J. Kaufman (2009), 2000 Temmuz ayında başlayan Camp David Zirvesi ile başlayan Filistin-İsrail müzakerelerinin başarısızlığını, tarafların rekabet halindeki ulusal kimlik anlatılarından kaynaklanan uzlaşmaz taleplerine dayandırmaktadır. Kaufman, aynı zamanda tarafların despotik/katı liderlerin uzlaşmayı engellemek ve çatışmayı tırmandırmak için duygusal sembolleri manipüle etmesini barışın korunmasında sorun teşkil ettiğini öne sürmektedir. Bu manipülasyon etnik anlaşmazlığın taraflarından biriyle yakın ittifak içinde olan bir arabulucu 
tarafından gerçekleştirildiğinde çatışma tırmanma riskiyle karşı karşıya kalabilir. Dolayısıyla arabulucunun iyi niyeti ve çözümcü yaklaşımı, barış tesisi adına oldukça belirleyicidir. Örneğin, 2000 yılında Amerika Birleşik Devletleri'nin (ABD) İsrail ile Suriye arasında bir anlaşmaya varmadaki başarısızlı̆̆ı, çözümcü ve önyargısız bir yaklaşımın ve uzlaşmacı kazan-kazan önerilerinin temin edilemediği bir atmosferin sonucudur (Pressman, 2007). Müzakereler öncesinde olduğu gibi müzakereler sırasında da ABD tarafsız olmaktan ziyade, sık sık İsrail'in pozisyonunu destekleyen aktör olarak çözümsüz bırakılan tarafın (veya dezavantajı tarafın) güvenini kaybetmiştir. Sonuç olarak çözüm dışı bırakılan ve hoşlanılmayan taraf, arabulucuya ve müzakere sürecine olan güvenini yitirme durumuyla karşı karşıya kalabilir (Smith, 1985). Dolayısıyla çatışma çözümü ve bir arada yaşama için üçüncü taraflar dahil tüm tarafların niyet okumasız, tarafsız, önyargısız, işbirlikçi ve uzlaşmacı olması beklenir. Aksi takdirde güçlü tarafın fırsatçı ve uzlaşmaz tutumları, uluslararası ilişkilerde çatışma çözümüne olan güveni azalabileceği gibi etnik çatışmaların devamında gruplar arasında etnosantrik tutumları besleyen güvensizlik ve korku duygularının yerleşikmesine neden olabilir. Etnosantrik tutumları en aza indirgeyen bir müzakere süreci ise oluşabilecek diğer etnik meselelerin çözümünde umut verici bir gelişme halini alabilir. Örneğin başarılı geçen bir İsrail-Suriye müzakere süreci, İsrail-Lübnan çatışmasının çözümünde model olabilirdi. Dahası, bu müzakere süreci başarılı olsaydı Hizbullah’ın manevra gücünü kısıtlayıcı süreçler başlatılabilirdi (Pressman, 2007).

Etnik çatışmalar sırasında ve sonrasında barış girişimlerini zorlayan belki de en önemli husus, Soğuk Savaş'ın başlangııından bu yana, Uluslararası İlişkiler literatürünün en önemli araştırma alanlarından olan "güvenlik ikilemi"dir (Roe, 2007). Barry Posen (2003)'e göre devlete olan güvenin azalması ve olası bir anarşi durumunun hissedildiği ortamda, etnik grup bireyleri kendilerini koruyacak bir devlet olmaması algısına karşılık birdenbire kendilerini kendi güvenliklerinden sorumlu hissedebilmektedir. Etnik gruplar arasında gerçekleşen çatışmalar; güvensizliği ve korkuyu beslerken güvenlik ikilemi de yaratarak "ilk eyleme geçenin avantajı" algısı yaratmaktadır (Kaufmann, 1996; Gürses ve Rost, 2013). Dahası etnik ilişkilerde gerçekleşen güvenlik ikileminin yarattığı güvenlik açmazı durumu, gruplar ve komşular arasındaki sınırların ve siyasi karar alıcıların yeniden müzakere edilmesini beraberinde getirebilir. Özellikle liderler, kaynakların doğrudan ve dolaylı olarak izleyenlerine dağıtılması ile kaynak kontrolü sağladıklarında grup normları yoluyla izleyenlerini güçlü bir şekilde birleştirebilir. Bu durum ayrımcı siyasetin geliştiği ortama neden olabilir (Worsnop, 2017). Böylece, devletin yönetenlerine karşı güvensizlik, iç içe yaşadığı diğer etnik gruplarla fırsat eşitsizliği ve diasporadaki etnik gruplarla siyasi seferberlik, güvenlik ikilemini çözümü zor bir noktaya götürebilir. Zamanla kesinliğini kaybeden güvenli olma hali durumunda panik grup bireyleri, sınırları içerisindeki ve dışındaki etnik komşularını tehdit olarak görebilir ve rekabetçi siyasi seferberlikler gerçekleşme eğilimine girebilirler. Böyle bir durumda bir grubun güvenliğini artırmak için yaptığı şey, başka bir grubun güvenliğini (güvende olduğu hissini) azaltabilir (Rose, 2000). Diğer bir deyişle, bir grup kendini tehdit altında hissederse, diğer grubun/grupların güvenliğini azaltacak şekillerde kendi güvenliğini sağlamak için tepki verme eğilimini korumak isteyecektir. Bu eğilim de araştırmacılara güvenlik ikileminin yoğun olduğu durumlarda etnik çatışmanın/savaşın daha muhtemel olduğunu göstermektedir (Posen, 2003; Rose, 2000). Diğer yandan, müzakereler sırasında taraflar arasında siyaseti barışçıl şekilde yönlendiren "etnik sözleşmeler", etnik güç dengesindeki değişimlerle veya grupların başka aktörler hakkındaki inanç, tutum ve algılarındaki değişiklikler tarafından zayıflatılabilir. Yani, barış inşası çabaları sonucu gerçekleştirilen etnik taraflar arasındaki anlaşmalarda 
konjonktürel ve algısal değişimler (bir grubun diğer gruptan/gruplardan daha fazla avantaj elde ettiğine dair zamanla yerleşen algılar, siyasi liderlerin güç ve prestij kaybı ve/veya konjonktürel etkide değişen güç dağılımı vb.) etnik sözleşmelere/anlaşmalara yönelik güveni zayıflatabilir (Rose, 2000: 35). Görüldüğü üzere aslında etnik çatışmalar sırasında veya sonrasında oluşan güvenlik ikilemi, görünmez bir alanda algıların ve duyguların restleştiği bir zemin hazırlamaktadır (Roe, 2007).

\section{Sonuç}

Şiddetin ardından susturulmuş travma, uzunca bir süre uluslararası güvenlik araştırmaları tarafından ihmal edilmiştir. Esasen travmalar ve ardından inşa edilen anlatı çerçeveleri, küresel güvenliği derinden etkilemektedir. Bilindiği gibi uluslararası ilişkiler disiplininde kalıcı dost ve kalıcı düşman kavramları yer almaz. Ancak sekter nefretler gibi çeşitli duygu ve etnosantrik tutumların dinamiklerini taşıyan etnik çatışmalar, maalesef müzmin (intractable) denen çatışma modelini güçlendirmektedir. Kimlik krizi ile seyreden anlaşmazlıklarda, seçilmiş travmalar ve nostaljik anlatılar siyasallaşabilir ve kalıcı model ilişkilerin ortaya çıkardığı bir sistem yaratabilir. Şiddetin ardından sosyal olarak inşa edilen sınırlar, etnosantrik eğilimlerin derecesini artırarak kutuplaşmayı ve belirli davranış modellerini ortaya çıkarabilir. Şiddet içeren travmaları deneyimlemiş toplumlar, deneyim ve anlatılarını bir sonraki nesillere aktarmak isterler. Anlatıların amacı ise farkındalık yaratmaktır. Anlatı çerçeveleri ile birlikte karşı taraf dışlanır veya insanlıktan çıkarılırken, aslında grup içi kimliğe de yatırım yapılmaktadır. Volkan (2013), çatışmaya yönelik anlatı yaklaşımlarında gerçekle gerçek dışının harmanlanarak yeniden yaratıldığını ifade etmektedir. Taraflar hikayelerini aktif olarak yeniden yaratırken, diğer tarafın hikayelerine meydan okuyan, çatışan ve aynı zamanda çatışmayı tırmandıran çatışma risklerini ve dinamiklerini de inşa ederler. Bu nedenle travma sonrası bir araya gelen topluluk; pozitif veya terapötik bir topluluk olmaktan ziyade "aşındırıcı" bir nitelik göstermektedir (Schick, 2011: 1841).

Travmaların etnikler arası ilişkileri olumsuz yönde etkilediği varsayımı literatürde genel anlamda kabul edilmektedir. Yaşanılan sosyal ve siyasal problemlerde pek çok etmenin yanında, travmalar ve geçmişin izleri belirleyici olsa da etnik sorunlara kitlesel ruminasyon odaklı yaklaşmak, meseleleri çözümsüz bir döngüye hapsedebilir. Empatik tutumların gelişimiyle mevcut etnik düşmanlık ve şikâyetler, ortak çıkarlar bağlamında ve etnik işbirliğini daha belirgin hale getiren yeni çarelerle hafifletilebilir. Aksi halde, dünya çapındaki sayısız çatışma ve doğal sonucu olarak travmatik toplumlar, çatışmaya gömülü bırakılan ve sonu gelmeyen yıkıcı dinamiklerin kısır döngüsüne dönüşebilir. Nitekim, toplumlararası husumeti sürekli kılan etmenlerin karşılıklı olarak duygu üretimini tetiklediği ve kimlik krizinin de eklemlendiği bir ortamda bölgesel barışın tesisini gerçekleştirmek zor olabilir. Uluslararası terapötik müdahaleler, travmatik toplumların rehabilitesinde bir noktaya kadar oldukça anlamlı ve gereklidir. Ancak müdahaleler, bu toplumların iç dinamiklerini kısıtlayıcı yönde etkileyebilmektedir. Örneğin Bosna Savaşı'nda ABD'nin etkinliğiyle Dayton Barış Anlaşması imzalanmıştır. Bu anlaşma zemininde, Balkanlar'daki güçlü etnik gruplar arasındaki iç savaşları ve çatışmaları yönetmek için $A B D$ ve müttefiklerinin ciddi derecede müdahalesine dayanan uluslararası yaklaşım hâkim olmuştur. Benzer olarak ABD, Orta Doğu'da merkezi bir oyuncu olduğu gibi İsrail ile Filistin ve İsrail ile Suriye arasındaki çatışmada baskın bir arabulucu olmuştur. Ortadoğu, Balkan ve Afrika gibi dünyanın çeşitli bölgelerindeki devletlerin siyasal yapısının bir özelliği haline gelen müzmin çatışmaları dönüştürmek ve tarafları uzlaştırmak için kaynakların sağlanması sadece ekonomi ve kalkınma meselesi değildir. Taraflar arasında 
sorumluluğun ve hesap verilebilirliğin olduğu stratejik sözleşmelere dayalı ve ortak çıkarlar çerçevesinde işbirliği tesisi sağlayan proaktif önlemler de bu anlamda önemli olabilir. Barışın tesisini dış kaynaklarda aramak yerine, etnosantrik tutumları en aza indirgeyen bir yaklaşımla kültürel etkileşim, karşılıklı çıkar ve bir arada yaşama gibi iç kaynakların dinamiklerinde aramak daha rasyonel olabilir.

Etnik çatışmaların nedenleri çok çeşitli olabilir, ancak neredeyse tüm etnik çatışmaların ortak yönlerinden biri, egemen bir devletin sınırları içinde yaşayan birden fazla grubun birbirlerine yönelik tutumlarıdır. Bosna, Sri Lanka, Kıbrıs ve Güney Afrika gibi etnik anlaşmazlıklara yönelik barış müzakereleri, etnik gruplara kendi grupları hakkında kararlar alabileceği bir tür yetki devri/paylaşımı sağlamayı hedeflemiştir. Bu girişimler, her ne kadar bir etnik grubun diğer etnik gruplar üzerinde güç egemenliğini (olumlu yönde) kısıtlayıcı amaç taşısa da, grup içi kayırmacılığı artıran etnosantrik yönelimleri besleyen olumsuzlukları da barındırmaktadır. Bu durumda, karşı tarafın daha fazlasını elde etmemesi için çeşitli alanlarda eşit/adil paylaşıma uygun bir işbirliği (kazan-kazan) anlayışı üretilmesi önemlidir. Diğer bir deyişle, sürdürülebilir barış için, tarafların etnik kimlik ve varoluş adına birbirlerini sıfır toplamlı bir rekabet alanında görmek yerine, karşılıklı kazanımların sunulduğu ve çatışma yönetiminde metaforize edilmiş bir ifadeyle "anlaşma kutusu (agreement box)" oluşturulan bir ortamda ifade etmeleri, güven tesisi adına destekleyici olabilir. Bu noktada toplum bireylerine anlatı ve tutumlarını ılımlı yönlendirmede önemli bir görev düşmektedir.

Barış inşası toplum bireylerinin davranış, tutum ve algılarından tecrit edilmiş halde ve sadece devletlerin siyasi görev alanı olarak düşünülemez. Şiddete kalıcı bir son vermek için liderlerin ve halkların uzlaşmaya izin veren tutum, davranış ve anlatıları benimsemeleri ilk adım olarak gerekli olabilir. Tutum ve davranışları etkileyen anlatılar, toplumların duygularını yönlendiren temel unsurdur. Kaufman (2009: 404)'a göre "kalıcı barış, liderlerin ve halkların uzlaşmaya izin veren anlatıları benimsemelerini gerektirecektir." Dolayısıyla tarafların mağduriyet ve/veya üstünlüğüne dayanan ve grup çıkarlarını uzlaşmaz terimlerle tanımlayan düşmanca anlatı çerçeveleri, ılımlı bir hal almadan müzakereler ve arabuluculuk girişimlerinin başarılı olması zor görünmektedir. Müzakereler ve arabuluk girişimleri taraflardan birine daha yakın/taraflı olması çatışma duygusunun kalıcılaşması noktasında önemlidir. Dahası çatışma çözümü ve barış inşası için müzakerelere yön veren arabulucunun tutumu ve pozisyonu da çok önemlidir. İstenen bir çözüm olarak çatışmanın sağlıklı bir şekilde sona ermesine yönelik zorlukların kaynağı; hükümet politikaları, liderler, geçmiş yaşantıların bıraktığı izlerin etkisinden kaynaklı olabileceği gibi, çözüm arayışı içerisinde menfaatini düşünen, tarafgir ve çözüme yönelik net olmayan arabulucular da olabilir. İdeal olmayan ve güven sağlamayan başarısız bir müzakere süreci ise kutuplaşan gruplar arasında duygu üretiminin tetikleyicisi olarak güvenlik ikilemini sürdürebilir. 


\section{Kaynakça}

Allport, G. W., Clark, K., \& Pettigrew, T. (1954). The nature of prejudice.

Arıboğan, D. Ü. (2020). Politik Karar, Tutum ve Davranışlarımızı Bireyselden Toplumsala Uzanan Bir Yelpazede Anlama ve Açıklama Kılavuzu Olarak Politik Psikoloji. Üsküdar Üniversitesi Sosyal Bilimler Dergisi, (10), 37-62.

Armoudian, M. (2020). In search of a genocidal frame: Preliminary evidence from the Holocaust and the Rwandan genocide. Media, War \& Conflict, 13(2), 133-152.

Axelrod, R., \& Hamilton, W. D. (1981). The evolution of cooperation. science, 211(4489), 1390-1396.

Baele, S., Sterck, O., \& Meur, E. (2016). Theorizing and Measuring Emotions in Conflict: The Case of the 2011 Palestinian Statehood Bid. The Journal of Conflict Resolution, 60(4), 718-747.

Bar-Tal, D. (2001). Why does fear override hope in societies engulfed by intractable conflict, as it does in the Israeli society?. Political Psychology, 22(3), 601-627.

Baumeister, R. F., \& Hastings, S. (1997). Distortions of collective memory: How groups flatter and deceive themselves.

Behrendt, H., \& Ben-Ari, R. (2012). The Positive Side of Negative Emotion: The Role of Guilt and Shame in Coping with Interpersonal Conflict. The Journal of Conflict Resolution, 56(6), 1116-1138.

Billig, M. (1985). Prejudice, categorization and particularization: From a perceptual to a rhetorical approach. European Journal of Social Psychology, 15(1), 79-103.

Bigler, R. S., \& Liben, L. S. (2006). A developmental intergroup theory of social stereotypes and prejudice. In Advances in child development and behavior (Vol. 34, pp. 39-89). JAI.

Brandt, M. J., \& Crawford, J. T. (2020). Worldview conflict and prejudice. In Advances in Experimental Social Psychology (Vol. 61, pp. 1-66). Academic Press.

Brown, R., \& Pehrson, S. (2019). Group processes: Dynamics within and between groups. John Wiley \& Sons.

Bulutgil, H. Z. (2018). The state of the field and debates on ethnic cleansing. Nationalities Papers, 46(6), 1136-1145.

Bush, R. A. B., \& Folger, J. P. (2004). The promise of mediation: The transformative approach to conflict. John Wiley \& Sons.

Buzan, B. (1984). Peace, power, and security: contending concepts in the study of International Relations. Journal of Peace Research, 21(2), 109-125.

Capucao, D. D. (2010). Religion and ethnocentrism: an empirical-theological study. Brill.

Charny, I. W. (1982). How can we commit the unthinkable. Genocide: The human cancer, 2-33.

Chiozza, G., \& Goemans, H. E. (2011). Leaders and international conflict. Cambridge University Press.

Collins, C. (2012). Understanding Intractable Conflict in Sudan. American Intelligence Journal, 30(1), 23-26.

Connerton, P. (1989). How societies remember. Cambridge University Press.

Croco, S. E. (2011). The decider's dilemma: Leader culpability, war outcomes, and domestic punishment. American Political Science Review, 105(3), 457-477.

Devine, P. G. (1989). Stereotypes and prejudice: Their automatic and controlled components. Journal of personality and social psychology, 56(1), 5.

Diehl, P. F., \& Lepgold, J. (Eds.). (2003). Regional conflict management. Rowman \& Littlefield Publishers.

Eber, D. E., \& Neal, A. G. (2001). Memory and representation: constructed truths and competing realities. Popular Press. 
Eggert, M., \& Falzon, W. (2018). Resolving Conflict. Management Pocketbooks.

Fischer, A. H., \& Roseman, I. J. (2007). Beat them or ban them: The characteristics and social functions of anger and contempt. Journal of personality and social psychology, 93(1), 103.

Frijda, N. H. (2004, April). Emotions and action. In Feelings and emotions: The Amsterdam symposium (pp. 158-173).

Gangopadhyay, P., \& Chatterji, M. (Eds.). (2009). Peace science: theory and cases. Emerald Group Publishing.

Greenwald, A. G., \& Banaji, M. R. (1995). Implicit social cognition: attitudes, self-esteem, and stereotypes. Psychological review, 102(1), 4.

Gurses, M., \& Rost, N. (2013). Sustaining the peace after ethnic civil wars. Conflict Management and Peace Science, 30(5), 469-491.

Duffield, M. (2001). Governing the borderlands: decoding the power of aid. Disasters, 25(4), 308320.

Eriksen, T. H. (1993). Ethnicity and Nationalism: Anthropological perspectives.(ed.)

Haer, R., \& Böhmelt, T. (2017). Could rebel child soldiers prolong civil wars. Cooperation and Conflict, 52(3), 332-359. doi:10.2307/48512949

Hammond, R. A., \& Axelrod, R. (2006). The evolution of ethnocentrism. Journal of conflict resolution, 50(6), 926-936.

Halperin, E., \& Pliskin, R. (2015). Emotions and emotion regulation in intractable conflict: Studying emotional processes within a unique context. Political Psychology, 36, 119-150.

Horowitz, D. L. (2000). Ethnic groups in conflict. University of California Press.

Horowitz, M. C., \& Starn, A. C. (2014). How prior military experience influences the future militarized behavior of leaders. International Organization, 527-559.

Horowitz, M. C., \& Fuhrmann, M. (2018). Studying Leaders and Military Conflict: Conceptual Framework and Research Agenda. Journal of Conflict Resolution, 62(10), 2072-2086.

Horowitz, M. C., Potter, P., Sechser, T. S., \& Stam, A. (2018). Sizing Up the Adversary: Leader Attributes and Coercion in International Conflict. Journal of Conflict Resolution, 62(10), 2180-2204.

Katz, D., \& Braly, K. W. (1933). Verbal stereotypes and racial prejudice. Journal of abnormal and social psychology, 28, 280-290.

Kaufman, S. J. (1996). Preventive peacekeeping, ethnic violence, and Macedonia. Studies in conflict \& terrorism, 19(3), 229-246.

Kaufman, S. J. (2009). Narratives and symbols in violent mobilization: the Palestinian-Israeli case. Security Studies, 18(3), 400-434.

Kelman, H. C. (1997). Social-psychological dimensions of international conflict. Peacemaking in international conflict: Methods and techniques, eds. I. William Zartman and J. Lewis Rasmussen, Washington DC: United States Institute of Peace Press ,191-237.

Kelman, H. C. (1999). Interactive problem solving as a metaphor for international conflict resolution: Lessons for the policy process. Peace and Conflict, 5(3), 201-218.

Kelman, H. (2006). The role of an international facilitating service for conflict resolution. International Negotiation, 11(1), 209-223.

Khmelko, I., \& Wiegand, K. (2010). Government Repressıon In Ethnıc Conflıct: Instıtutıonal Incentıves And Cultural Legacies. International Journal on World Peace, 27(2), 7-34.

Kinder, D. R., \& Kam, C. D. (2010). Us against them: Ethnocentric foundations of American opinion. University of Chicago Press. 
Kurzban, R., Tooby, J., \& Cosmides, L. (2001). Can race be erased? Coalitional computation and social categorization. Proceedings of the National Academy of Sciences, 98(26), 15387-15392.

Lederach, J. P. (1997). Sustainable reconciliation in divided societies. Washington, DC: USIP.

Lewicki, R., Gray, B., \& Elliott, M. (Eds.). (2003). Making sense of intractable environmental conflicts: Concepts and cases. Island press.

Lederach, J. P. (1997). Sustainable reconciliation in divided societies. Washington, DC: USIP.

Levine, R. A., \& Campbell, D. T. (1972). Ethnocentrism: Theories of conflict, ethnic attitudes, and group behavior.

Levy, J. S. (1994). Learning and foreign policy: Sweeping a conceptual minefield. International organization, 48(2), 279-312.

Mair, L. (1975). 'Ethnocide'. RAIN, (7), 4-5.

McDoom, O. (2012). The Psychology of Threat in Intergroup Conflict: Emotions, Rationality, and Opportunity in the Rwandan Genocide. International Security, 37(2), 119-155.

Messmer, H. (2007). Contradiction, conflict and borders. na.

Midlarsky, M. I. (2005). The killing trap: Genocide in the twentieth century. Cambridge University Press.

Murer, J. S. (2009). Constructing the enemy-other: Anxiety, trauma and mourning in the narratives of political conflict. Psychoanalysis, Culture \& Society, 14(2), 109-130.

Murer, J. S. (2010). Institutionalizing enemies: The consequences of reifying projection in postconflict environments. Psychoanalysis, Culture \& Society, 15(1), 1-19.

Mann, M., \& Doğan, B. O. (2012). Demokrasinin karanlık yüzü: etnik temizliği açıklamak. İthaki.

Mead, G. H. (1934). Mind, self and society (Vol. 111). University of Chicago Press.: Chicago.

Pender, J. (2002). Empowering the poorest? The world bank and the 'Voices of the Poor'. In Rethinking Human Rights (pp. 97-114). Palgrave Macmillan, London.

Posen, B. R. (2003). The security dilemma and ethnic conflict. In Perspectives on Structural Realism (pp. 83-104). Palgrave Macmillan, New York.

Pratto, F. (1999). The puzzle of continuing group inequality: Piecing together psychological, social, and cultural forces in social dominance theory. In Advances in experimental social psychology (Vol. 31, pp. 191-263). Academic Press.

Pressman, J. (2007). Mediation, domestic politics, and the Israeli-Syrian negotiations, 1991-2000. Security Studies, 16(3), 350-381.

Pupavac, V. (2002). Pathologizing populations and colonizing minds: International psychosocial programs in Kosovo. Alternatives, 27(4), 489-511.

Pupavac, V. (2004). War on the couch: the emotionology of the new international security paradigm. European journal of social theory, 7(2), 149-170.

Ratner, T. J., \& Enders, F. S. Scapegoat Theory: Shifting Blame and Displacing Aggression.

Ray, L. (1999). Memory, trauma and genocidal nationalism. Sociological Research Online, 4(2), 125132.

Santayana, G. (1905). Those who cannot remember the past are condemned to repeat it. Santayana G: Reason in Common Sense: The Life of Reason. New York, Charles Scribner, 284Santayana.

Schick, K. (2011). Acting out and working through: trauma and (in) security. Review of International Studies, 1837-1855.

Schwartz, S. H., \& Struch, N. (1989). Values, stereotypes, and intergroup antagonism. In Stereotyping and prejudice (pp. 151-167). Springer, New York, NY. 
Sechser, T. S. (2004). Are soldiers less war-prone than statesmen?. Journal of conflict resolution, 48(5), 746-774.

Singh, M. (2002). Ethnic Conflict And International Security: Theoretical Considerations. World Affairs: The Journal of International Issues, 6(4), 72-89.

Sumner, W. G. (1906). Folkways: A Study of the Sociological Importance of Usages. Manners, Customs, Mores, and Morals, Ginn \& Co., Boston, MA.

Smith, W. P. (1985). Effectiveness of the biased mediator. Negotiation journal, 1(4), 363-372.

Staub, E. (1989). The roots of evil: The origins of genocide and other group violence. Cambridge University Press.

Sternberg, R. J. (2005). The psychology of hate. American Psychological Association.

Tint, B. (2010). History, memory, and intractable conflict. Conflict Resolution Quarterly, 27(3), 239256.

Trolier, T. K., \& Hamilton, D. L. (1986). Variables influencing judgments of correlational relations. Journal of Personality and Social Psychology, 50(5), 879.

Wondolleck, J. M., Gray, B., \& Bryan, T. (2003). Us versus them: How identities and characterizations influence conflict. Environmental Practice, 5(3), 207-213.

Volkan, V. D. (1996). Bosnia-Herzegovina: Ancient fuel of a modern inferno. Mind and Human Interaction, 7(3), 110-127.

Volkan, V. D. (2003). Large-group identity: Border psychology and related societal processes. Mind and Human Interaction, 13(1), 49-76.

Volkan, V. D. (2005). Körü Körüne İnanç,(çev.) Dr. Özgür Karaçam, Okuyan Us, İstanbul.

Volkan, V. D. (2009). Large-group identity:'Us and them'polarizations in the international arena. Psychoanalysis, Culture \& Society, 14(1), 4-15.

Volkan, V. D. (2011). Unending mourning and its consequences. Psychotherapie-Wissenschaft, 1(2), 102-110.

Volkan, V. D. (2013). Divandaki düşmanlar: bir Türk psikanalistin siyaset psikolojisi serüveni. Alfa.

William Rose (2000) The security dilemma and ethnic conflict: Some new hypotheses, Security Studies, 9:4, 1-51

Worsnop, A. (2017) Who Can Keep the Peace? Insurgent Organizational Control of Collective Violence, Security Studies, 26:3, 482-516,

Zartman, I. W. (2007). Negotiation and conflict management: Essays on theory and practice. Routledge.

Zerubavel, Y. (1995). Recovered roots: Collective memory and the making of Israeli national tradition. University of Chicago Press. 


\section{Extended Summary}

\section{A Political Psychological Analysis on Ethnic Conflicts and Peace Studies}

We build our world with our intentions, decisions, actions, and perceptions. In doing so, we need to belong to a certain community and move forward with that community's norms. At this point, the issue of belonging arises, expressing who we are and where we belong. Ethnic identity and belonging to the ethnic group have certain social boundaries. The imaginary features of ethnic communities are very important for group members. Because ethnic belonging, as an indicator of where the individual belongs, offers an important narrative and ideological field. The "myth-symbol-memory trinity", as the elements that strengthen belonging, blends the individual with the group to which he/she belongs and gives direction to his/her emotions that connect with the past. The reflections of the society belonged to and the heavy reckoning it lived in is sacred for both traumatized societies and future generations. This situation also creates an unlimited memory and emotional depot. As a provider of ethnic perpetuity, these arguments are absorbed by future generations as "Psychological DNA", in the words of Vamık Volkan, within the "victim and survivor" narrative frameworks. Group members can refer to this material to create a legitimate basis when they experience moral separation and group regression. Although the traumas and subsequent narratives are related to heroism and victimization, they are mainly related to hostility. In this case, like the lens effect, the enemy is perceived as larger than it is since the trauma has a far-reaching effect. This situation may create an environment for an exclusion policy that fosters intractable conflicts. Indeed, this creates a security dilemma that causes cold or hot conflicts to continue between groups. As a matter of fact, each ethnic group has its own "conformity" standards since it is not isomorphic (uniform/coordinated). Especially in times of crisis, these standards can trigger ethnocentric behavior patterns and may be desired to be revealed in a cultural context. Reason and logic can be ignored in cases of narratives and memory transfers accumulated by traumatized ethnic communities. These societies want to preserve some of the social boundaries they set in any crisis that reminds them of the past. In this situation, individuals of the collective are more prone to antipathy towards something unusual. Concern, anger, fear becomes involved in collective sadness over time. Assumed common ancestor, racial traits, cultural features, or primitive feelings of a common ethnic background often increase the risk of exclusion and ensuing problems. Thus, the nature of group norms can direct people's relationships with other groups and even shape aggressive behavior patterns.

Although the emotions of ethnic groups are worth studying in the name of conflict management, peace studies, and international security, the role of emotions in politics has long been left behind. Although this gap has gladly been reduced with the intertwined literature in the last decades, the motivation of the conflict has been studied through concrete elements for a long time. Therefore social traumas, suppressed emotions, and unresolved mourning are serious obstacles to peace studies. These obstacles strain mutual understanding and cooperation by maintaining stereotypes of thought and behavior. For this reason, emotions have been analyzed in a collective context in the focus of conflict resolution and peace studies recently. Political Psychology is an important field in the understanding and development of this approach. Negotiation processes are indispensable to facilitate peacebuilding and coexistence among societies that have experienced conflict in the past. The goal of negotiation processes is to provide the support of mutual trust rather than economic support packages or security projects, but in practice, this is very difficult to achieve. The main challenge is to ensure healthy interaction and competition between the parties. Building mutual trust does not mean that there should be no competition between groups. In order to manage a healthy post-conflict process and prevent subsequent conflicts, it is not necessary to ensure that there is no competition between the parties, but a competitive environment that supports development with social projects and incentives that will create mutual trust. In other words, a basis to support the win-win process should be established, not a zero-sum process between conflict parties. So competition is a catalyst and necessary to strengthen the economic, social, and political formations of their communities. In this sense, external forces should be supportive of this environment that is suitable for intervention and not be directing like 'a hand from above'. Unfortunately, the political environment in most of today's divided societies does not allow such a system due to insufficient encouragement of politicians from both inside and outside. Therefore, social unrest, which becomes permanent with the rejection of common ground by the political elites, is subject to the emotional manipulation of social groups and becomes a self-fulfilling prophecy.

Besides the traumas chosen as traces of past wounds nurture separatist behavior and attitudes in post-conflict divided societies, the main reason for permanent conflicts stems from unsuccessful negotiations and uncompromising peace attempts. Moreover, leaders and political decision-makers who can manipulate emotions and attitudes as motivators of ethnic conflicts can direct conflict as well as peace. Besides, apart from the human factor, borders, geography, neighborhood, regional conflict history can also be used in conflict resolution and emotional manipulation. Diplomatic processes realized after any political crisis are quite determinant in the political formation 
of the future. More importantly, negotiating processes with unsuccessful mediation and arbitration can increase biased narratives, ethnocentric tendencies, and emotional coldness that disadvantage in the name of peace between the conflicting parties. In the name of credibility in international security and conflict resolution, the sincere, prosolution, and conciliatory role of third parties that direct the conflict process is very crucial. In summary, peace studies should be strengthened not by trying to make us forget the traces of past lives, but by dealing with the traces of these experiences without getting away from the facts. Otherwise, conflicts will simply continue to be frozen without being stopped. 